\title{
Pretreatment of Americium/Curium Solutions for Vitrification(U)
}

by

T. S. Rudisill

Westinghouse Savannah River Company

Savannah River Site

Aiken, South Carolina 29808
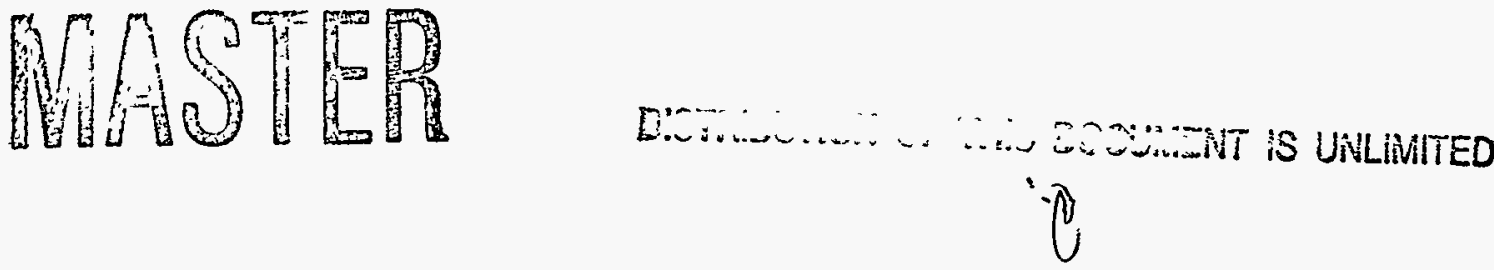

DOE Contract No. DE-AC09-89SR18035

This paper was prepared in connection with work done under the above contract number with the U. S.

Department of Energy. By acceptance of this paper, the publisher and/or recipient acknowledges the U.S. Government's right to retain a nonexclusive, royalty-free license in and to any copyright covering this paper, along with the right to reproduce and to authorize others to reproduce all or part of the copyrighted paper. 


\section{DISCLAMIIR}

Portions of this doewment may be illegible in electronic image products. Images are produced from the best available original document. 
WSRC-TR-96-0074

Revision 0

\title{
Pretreatment of Americium/Curium Solutions for Vitrification (U)
}

\author{
Tracy S. Rudisill
}

March 1996

Westinghouse Savannah River Company

P. O. Box 616

Aiken, SC 29808

Prepared by the U. S. Department of Energy under Contract ICO 229486JL 
WSRC-TR-96-0074

Revision 0

Pretreatment of Americium/Curium Solutions for Vitrification (U)

Tracy S. Rudisill

March 1996

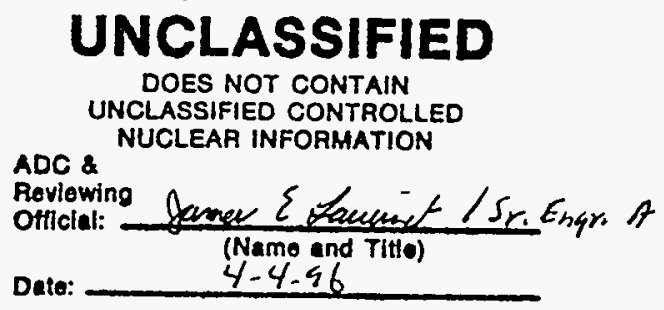


WSRC-TR-96-0074

Revision 0

\section{Pretreatment of Americium/Curium Solutions for Vitrification (U)}

\section{By}

Tracy S. Rudisill

Issued: March 1996

\section{Approvals}

\begin{tabular}{|c|c|}
\hline Tracy s. Rudisill & $3 / 18 / 96$ \\
\hline Tracy S. Rjodisill, Author & Date \\
\hline Majosc Thompson & $3 / 18 / 96$ \\
\hline Majo C. Thompson, Technicgl Reviewer & Date \\
\hline W3summer & $3 / 26 / 96$ \\
\hline
\end{tabular}


WSRC-TR-96-0074

Revision 0

\section{DISCLAIMER}

This report was prepared as an account of work sponsored by an agency of the United States Government. Neither the United States Government nor any agency thereof, nor any of their employees, makes any warranty, express or implied, or assumes any legal liability or responsibility for the accuracy, completeness, or usefulness of any information, apparatus, product, or process disclosed, or represents that its use would not infringe privately owned rights. Reference herein to any specific commercial product, process, or service by trade name, trademark, manufacturer, or otherwise does not necessarily constitute or imply its endorsement, recommendation, or favoring by the United States Government or any agency thereof. The views and opinions of authors expressed herein do not necessarily state or reflect those of the United States Government or any agency thereof.

This report has been reproduced directly from the best available copy.

Available to DOE and DOE contractors from the Office of Scientific and Technical Information, P.O. Box 62, Oak Ridge, TN 37831; prices available from (615) 576-8401.

Available to the public from the National Technical Information Service, U.S. Department of Commerce; 5285 Port Royal Road, Springfield, VA 22161. 


\section{Table of Contents}

Section

Page

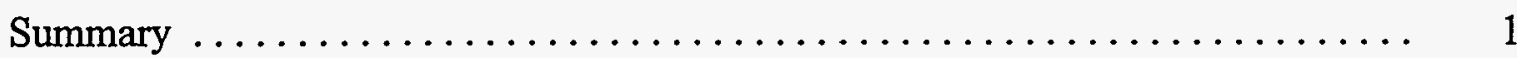

Introduction $\ldots \ldots \ldots \ldots \ldots \ldots \ldots \ldots \ldots \ldots \ldots \ldots \ldots \ldots, 2$

Background $\ldots \ldots \ldots \ldots \ldots \ldots \ldots \ldots \ldots \ldots \ldots \ldots \ldots \ldots \ldots \ldots \ldots, 2$

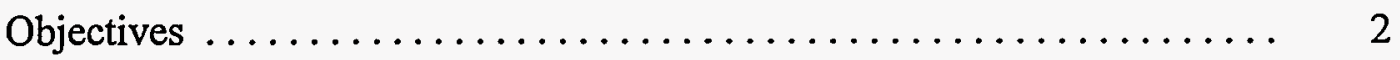

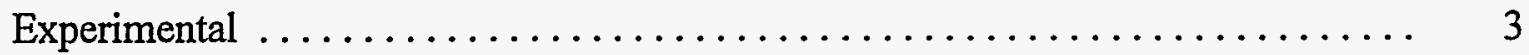

Uranium Solubility Experiments $\ldots \ldots \ldots \ldots \ldots \ldots \ldots \ldots \ldots \ldots \ldots \ldots$

Simulated Am/Cm Pretreatment Experiments ................ 3

Slurry Properties of Oxalate Precipitate $\ldots \ldots \ldots \ldots \ldots \ldots \ldots \ldots \ldots \ldots \ldots$

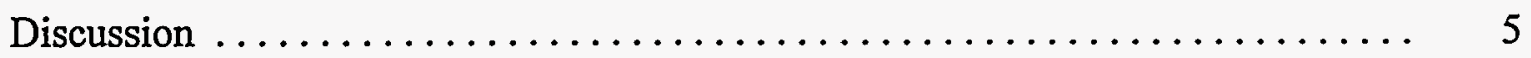

Solubility of Uranyl Oxalate $\ldots \ldots \ldots \ldots \ldots \ldots \ldots \ldots \ldots \ldots \ldots \ldots \ldots \ldots$

Simulated Am/Cm Pretreatment Experiments $\ldots \ldots \ldots \ldots \ldots \ldots \ldots .6$

Properties of Precipitate Slurry $\ldots \ldots \ldots \ldots \ldots \ldots \ldots \ldots \ldots \ldots \ldots \ldots . \quad 9$

Conclusions and Recommendations $\ldots \ldots \ldots \ldots \ldots \ldots \ldots \ldots \ldots \ldots \ldots, 10$

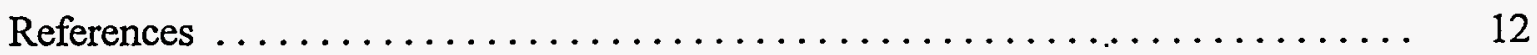




\section{List of Figures}

Page

Figure $1 \quad \mathrm{Am} / \mathrm{Cm}$ Purification in F-Canyon $\ldots \ldots \ldots \ldots \ldots \ldots \ldots \ldots$

Figure $2 \quad$ Small-scale Precipitation Equipment $\ldots \ldots \ldots \ldots \ldots \ldots \ldots \ldots$

Figure $3 \quad$ Large-scale Precipitation Equipment $\ldots \ldots \ldots \ldots \ldots \ldots \ldots \ldots$

Figure $4 \quad$ Solubility of Lanthanide Oxalates $\ldots \ldots \ldots \ldots \ldots \ldots \ldots \ldots \ldots$

Figure $5 \quad$ Solubility of Americium (III) Oxalate $\ldots \ldots \ldots \ldots \ldots \ldots \ldots$

Figure $6 \quad$ Solubility of Curium (III) Oxalate $\ldots \ldots \ldots \ldots \ldots \ldots \ldots \ldots$

Figure $7 \quad$ Solubility of Plutonium (IV) Oxalate $\ldots \ldots \ldots \ldots \ldots \ldots \ldots \ldots$

Figure $8 \quad$ Effect of Iron on the Solubility of Lanthanide Oxalates $\ldots \ldots \ldots 20$

Figure 9 Removal of Iron from Oxalate Precipitation Supernate $\ldots \ldots \ldots \ldots 21$

Figure $10 \quad$ Removal of Aluminum from Oxalate Precipitation Supernate $\ldots . \ldots \quad 22$

Figure 11 Removal of Sodium from Oxalate Precipitation Supernate . . . . . . 23 


\section{List of Tables}

\section{Page}

Table $1 \quad$ Chemical Analysis of Tank 17.1 Solution $\ldots \ldots \ldots \ldots \ldots \ldots . . \ldots 24$

Table 2 Operating Limits for $\mathrm{Am} / \mathrm{Cm}$ Purification in F-Canyon $\ldots \ldots \ldots \ldots 25$

Table 3 Uranium Oxalate Solubility Data $\ldots \ldots \ldots \ldots \ldots \ldots \ldots \ldots .26$

Table 4 Comparison of Measured and Calculated Uranium Concentrations ... 27

Table 5 Precipitation Conditions for $\mathrm{Am} / \mathrm{Cm}$ Pretreatment Experiments .... 28

Table 6 Oxalate Solubility Data for Experiment ACP-6 . . . . . . . . . 29

Table $7 \quad$ Oxalate Solubility Data for Experiment ACP-7 $\ldots \ldots \ldots \ldots \ldots . \quad 31$

Table $8 \quad$ Oxalate Solubility Data for Experiment ACP-8 $\ldots \ldots \ldots \ldots \ldots$

Table 9 Oxalate Solubility Data for Experiment ACP-9 $\ldots \ldots \ldots \ldots \ldots .35$

Table 10 Oxalate Solubility Data for Experiment ACP-10 .......... 36

Table $11 \quad$ Selected Stability Constants for Oxalic Acid $\ldots \ldots \ldots \ldots \ldots . . \ldots 38$

Table 12 Solution Analysis for Precipitate Slurry Scouting Experiments ..... 39

Table $13 \quad$ Specific Volume of Oxalate Slurry $\ldots \ldots \ldots \ldots \ldots \ldots \ldots \ldots .41$

Table 14 Oxalate Solubility Data for Experiment ACP-14 ............ 42 


\section{List of Appendices}

Page

Appendix A Preparation of Simulated Solutions $\ldots \ldots \ldots \ldots \ldots \ldots \ldots \ldots .43$

Appendix B Preparation of Oxalic Acid Solutions . ................. 50

Appendix C Preparation of Oxalic Acid/Nitric Acid Wash Solutions $\ldots \ldots \ldots .51$

vii 


\title{
Pretreatment of Americium/Curium Solutions for Vitrification (U)
}

\author{
Tracy S. Rudisill \\ Westinghouse Savannah River Company \\ Savannah River Site \\ Aiken, SC 29808
}

\begin{abstract}
Summary
Vitrification will be used to stabilize an americium/curium $(\mathrm{Am} / \mathrm{Cm})$ solution presently stored in F-Canyon for eventual transport to the heavy isotope programs at Oak Ridge National Laboratory. Prior to vitrification, an in-tank oxalate precipitation and a series of oxalic/nitric acid washes will be used to separate these elements and lanthanide fission products from the bulk of the uranium and metal impurities present in the solution. Pretreatment development experiments were performed to understand the behavior of the lanthanides and the metal impurities during the oxalate precipitation and properties of the precipitate slurry. The results of these experiments will be used to refine the target glass composition allowing optimization of the primary processing parameters and design of the solution transfer equipment.
\end{abstract}

A series of oxalate solubility experiments demonstrated that the uranium (VI) present in the Am/Cm solution is soluble under all anticipated in-tank processing conditions. Experiments were performed using an uranium concentration representative of the canyon tank and with the addition of lanthanum to investigate the co-precipitation of a double salt. Non-radioactive experiments illustrated that the solubility of the lanthanides increased with decreasing excess oxalic acid concentration and that metal impurities will remain soluble during in-tank processing. The majority of the lanthanides and plutonium and essentially all of the $\mathrm{Am} / \mathrm{Cm}$ will be isolated as a precipitate slurry during the oxalate precipitation. Unwanted, soluble materials, such as uranium, iron, aluminum, and sodium can be removed by decanting and washing with an oxalic/nitric acid solution.

The specific volume of the oxalate slurry and settling behavior of a simulated $\mathrm{Am} / \mathrm{Cm}$ precipitation were determined to define the in-tank settling time and the length of the solution transfer jet. The specific volume, 0.5 liters per mole of lanthanide/actinide simulant, was measured using non-radioactive surrogates and optimal precipitation conditions. When agitation was stopped, most of the precipitate settled in only a few minutes. The supernate was clear of all but the smallest particles after 30 minutes. The experiment also demonstrated that the precipitate will settle on any horizontal surfaces in a canyon tank such as cooling coils and agitator blades potentially leading to high losses when the supernate is removed. However, once settled to the bottom of the tank, the suction from a steam jet should not disturb the precipitate when placed as close as 1-inch from the top of the oxalate slurry. 


\section{Introduction}

\section{Background}

Approximately 15,000 liters of solution containing isotopes of $\mathrm{Am} / \mathrm{Cm}$ are currently stored in F-Canyon Tank 17.1 at the Savannah River Site (SRS). These isotopes were recovered during plutonium-242 production campaigns in the mid and late 1970's. The continued storage of these solutions was identified as an item of urgent concern in the Defense Nuclear Facility Safety Board's Recommendation 94-1. Currently there are no existing SRS facilities which can be used to stabilize this material for safe interim storage or transport to the heavy isotope programs at Oak Ridge National Laboratory. An analysis of several alternatives has resulted in the recommendation to stabilize the $\mathrm{Am} / \mathrm{Cm}$ in a high lanthanide glass. The Multi-Purpose Processing Facility in F-Canyon will be used for the vitrification process. Pretreatment operations will be performed in canyon vessels to separate the actinides and lanthanides from other impurities (primarily iron, aluminum, and sodium) before subsequent vitrification.

The contents of Tank 17.1 were sampled and characterized as part of the analysis of disposition options available for the $\mathrm{Am} / \mathrm{Cm}$. When Tank 17.1 was sampled it contained 15,140 liters and approximately $4 \mathrm{M}$ nitric acid. A summary of the chemical analyses are presented in Table 1 . The results are reported in mass units due to changes in the solution volume from evaporation and chemical additions. Power generation in the tank is approximately $7 \mathrm{~kW}$.

Pretreatment operations for the $\mathrm{Am} / \mathrm{Cm}$ stabilization include adjusting the nitric acid concentration of the Tank 17.1 solution to $<1 \mathrm{M}$, precipitating the actinides and lanthanides as oxalates, washing soluble metallic impurities from the precipitate slurry, solubilizing the precipitate, and adjusting the nitric acid concentration prior to vitrification. The flowsheet for these operations is based on previous development work and plant operating experience. The recovery of $\mathrm{Am} / \mathrm{Cm}$ from aluminum and sodium nitrate wastes using this flowsheet was developed by the Savannah River Laboratory (SRL) and a full-scale test was performed in FCanyon to recover $\mathrm{Am} / \mathrm{Cm}$ from a Mark 41 target waste solution. ${ }^{1,2}$ The flowsheet and operating conditions used during the test are shown on Figure 1 and Table 2, respectively.

\section{Objectives}

The Am/Cm pretreatment development program focused on the behavior of the lanthanides and the metallic impurities during the oxalate precipitation and properties of the precipitate slurry. Specific experimental needs included demonstration of the oxalate precipitation to measure the solubility of metallic impurities which have an impact on the glass formulation and measuring the settling rate and specific volume of the precipitate slurry to allow design of the solution transfer equipment. The results of the pretreatment experiments will be used to refine the target glass composition for detailed process design allowing optimization of the primary processing parameters of glass liquidus and viscosity. The settling rate and specific volume of the precipitate slurry are required to define the settling time during in-tank processing and the 
minimum height at which the solution transfer jet must be located above the slurry to prevent entrainment of solids.

\section{Experimental}

\section{Uranium Solubility Experiments}

In order to minimize the handling of radioactive samples, uranium oxalate solubility experiments were performed without simulating the exact chemical composition of Tank 17.1. Two experiments were performed using an uranium concentration representative of the tank. The three remaining experiments were performed with an amount of lanthanum equal to the molar concentration of the lanthanides and actinides (excluding uranium) which are in the tank (i.e. elements which precipitate). These experiments were designed to determine if uranium would co-precipitate as a double salt with insoluble species during in-tank processing. The preparation of the simulated solutions and oxalate precipitate used for these experiments is summarized in Appendices A and B, respectively.

The uranium solubility experiments were performed using a 1 liter, three-neck flask shown schematically on Figure 2. The flask was immersed in a constant temperature bath which was used for temperature control. A graduated addition funnel with stopcock was used to add oxalic acid at a controlled rate. The oxalate precipitations were performed by adding a $250 \mathrm{ml}$ aliquot of simulated solution to the flask, heating the solution to $60^{\circ} \mathrm{C}$, and adding a measured volume of $0.9 \mathrm{M}$ oxalic acid over 15 to 30 minutes. The excess oxalic acid concentration was varied from 0.3 to $0.6 \mathrm{M}$ during 5 experiments. The solution was stirred (at $300 \mathrm{rpm}$ ) using a glass stirring rod with 2 sets of paddle blades. Once the oxalic acid addition was complete, the flask contents were cooled to $45^{\circ} \mathrm{C}$ (with continual stirring) and held for 4 hours. Multiple samples of the precipitation supernate were taken after the flask contents were allowed to settle over night. Samples were removed from the flask using a $10 \mathrm{ml}$ disposable syringe. The solution was then expelled through an 0.45 micron filter disk into the sample bottle. During the first four experiments, the flask contents were allowed to cool over night. The temperature of the supernate was typically between 15 and $20^{\circ} \mathrm{C}$. The temperature of the supernate in the final experiment was maintained at $35^{\circ} \mathrm{C}$ using the constant temperature bath to simulate radiolytic heating in Tank 17.1 .

\section{Simulated $\mathrm{Am} / \mathrm{Cm}$ Pretreatment Experiments}

Non-radioactive pretreatment experiments were performed using a simulated solution with elemental concentrations representative of Tank 17.1. Equal molar concentrations of the corresponding lanthanides (samarium, europium, and gadolinium) were used as surrogates for plutonium, americium, and curium. The presence of chromium in Tank 17.1 was not simulated to prevent the generation of a hazardous liquid waste. The solubility of chromium during an oxalate precipitation was assumed to mimic the behavior of other transition metals present in the 
tank such as iron and manganese. The technical basis for this assumption is given during the discussion of oxalate solubilities. The preparation of the simulated Tank 17.1 solution for these experiments is summarized in Appendix A.

The pretreatment experiments were performed using a three-neck flask identical to the one used for the uranium solubility experiments (see Figure 2). The oxalate precipitations were performed by adding a $250 \mathrm{ml}$ aliquot of simulated solution to the flask, heating the solution to $60^{\circ} \mathrm{C}$ with a constant temperature bath, and adding a measured volume of $0.9 \mathrm{M}$ oxalic acid over 15 to 30 minutes. The excess oxalic acid concentration was varied from 0.15 to $0.6 \mathrm{M}$ during 5 experiments. Preparation of the oxalic acid is summarized in Appendix B. The solution was stirred (at $300 \mathrm{rpm}$ ) using a glass stirring rod with 2 sets of paddle blades. Once the oxalic acid addition was complete, the flask contents were cooled to $45^{\circ} \mathrm{C}$ (with continual stirring) and held for 4 hours. The temperature was then adjusted to $35^{\circ} \mathrm{C}$ (to simulate radiolytic heating) and the flask contents were allowed to settle over night.

Following the removal of samples using the same technique described for the uranium experiments, a volume of supernate approximately equal to the precipitant volume (minus the sample volume) was removed from the flask. The solution was transferred using a dip leg inserted into the flask which was connected to a receipt tank under vacuum (see Figure 2). The depth of the dip leg was calibrated to leave approximately $250 \mathrm{ml}$ of solution in the flask. The precipitate was then washed using a $250 \mathrm{ml}$ aliquot of $0.25 \mathrm{M}$ oxalic acid/ $0.5 \mathrm{M}$ nitric acid solution. The preparation of the wash solution is summarized in Appendix C. The wash solution was added using the addition funnel over 15 to 30 minutes. Once the addition was complete, the solution was stirred for an additional 15 minutes and allowed to settle for 1 hour. A volume of supernate approximately equal to the wash volume was then removed by vacuum transfer. Samples of the wash solution were taken at this time. The wash procedure was repeated 4 times for a total of 5 wash cycles. All washes were performed at $35^{\circ} \mathrm{C}$. The precipitate slurry was then dissolved in nominally $8 \mathrm{M}$ nitric acid by adding a $250 \mathrm{ml}$ aliquot of concentrated (15.7M) nitric acid and heating at $65^{\circ} \mathrm{C}$ for 30 minutes. Samples of the dissolved slurry were then taken for analysis.

\section{Slurry Properties of Oxalate Precipitate}

Initially, three small-scale scouting experiments (ACP-11, ACP-12, and ACP-13) were conducted in a $1000 \mathrm{ml}$ graduated cylinder to develop the methodology to accurately measure the specific volume of the oxalate slurry. The cylinder was placed on a hot plate with a magnetic stirrer, which was used for both heating and stirring. The oxalic acid was added using the addition funnel used for the Tank 17.1 solubility experiments. A calibrated mercury-filled thermometer was used for temperature measurements. The preparation of the simulated solutions and 0.9M oxalate acid used for these experiments is summarized in Appendices $\mathrm{A}$ and $\mathrm{B}$, respectively. 
The settling rate and specific volume of the oxalate precipitate slurry were measured using a glass precipitator fabricated from $120-\mathrm{mm}$ tubing with a $150-\mathrm{mm}$ jacket (see Figure 3 ). The vessel was approximately $530-\mathrm{mm}$ tall. Ports in the precipitator head allowed the insertion of a stirrer, glass thermowell, thermometer, and dip leg for solution transfer. A port was also provided for the addition of oxalic acid and the removal of samples. The stirrer assembly was fabricated from a glass rod with two sets of paddle blades. During equipment testing it was necessary to add an approximate 1-inch thick Teflon ${ }^{\mathrm{TM}}$ disk with a centering hole to prevent the stirrer from wobbling. The temperature of the solution inside the precipitator was controlled using a Fisher Scientific Programmable Circulator (Model 9110). The circulator was equipped with a remote sensing probe which was inserted into the glass thermowell. However, a calibrated mercury-filled thermometer was the primary indication of the precipitator temperature.

A 7-mm (OD) tube was originally provided for the removal of supernate from the precipitator. However, the flow resistance of the small-diameter tube was too high to achieve linear fluid velocities comparable to the velocities achieved by canyon solution transfer jets. Velocities in excess of the canyon transfer jets were achieved by using a 10-mm (OD) tube inserted through the precipitator thermowell port. A 9 liter bottle was used as the solution receipt vessel. Vacuum was supplied using a GCA Corporation Precision Vacuum Pump (Model PV35). Solution was transferred by evacuating the receipt vessel and opening a control valve to siphon liquid from the precipitator. The procedure was analogous to the method used to remove the wash solution during the Tank 17.1 solubility experiments. The oxalate precipitate was pumped into the precipitator using a Cole-Parmer Instrument Company Masterflex ${ }^{\oplus}$ pump. A calibrated scale on the outside wall of the inner vessel was used to measure the oxalate slurry volume. The preparation of the simulated Tank 17.1 solution and $0.9 \mathrm{M}$ oxalic acid precipitate is summarized in Appendices A and B, respectively.

\section{Discussion}

\section{Solubility of Uranyl Oxalate}

The analytical results from the uranium solubility experiments are summarized in Table 3. During the five experiments, the oxalic acid concentration was varied from 0.3 to $0.6 \mathrm{M}$. The resulting concentrations of uranium, lanthanum, and nitric acid are listed in the table. The concentration of uranium calculated using the simulant concentrations and the volume of oxalic acid added during the precipitation (assuming complete solubility) is also listed in the table. Comparison of the average uranium concentration measured in the supernate from each precipitation and the calculated value using a t-test shows no statistical difference between the means (see Table 4). This clearly shows that uranium (VI) oxalate is soluble under these conditions. This observation is consistent with the literature, as soluble uranyl oxalate complexes involving mixed compounds, such as aquo-oxalates, aquo-carbonates, aquo-sulfatooxalates, and aquo-fluoro-oxalates have been reported. ${ }^{3}$ 


\section{Simulated Am/Cm Pretreatment Experiments}

The experimental conditions and analytical results from the simulated $\mathrm{Am} / \mathrm{Cm}$ pretreatment experiments are summarized in Tables 5-10. Table 5 lists the excess oxalic and final nitric acid concentrations and the number of wash cycles completed for each experiment. The excess oxalic acid concentration was calculated assuming complete precipitation of the lanthanides and complete solubility of the metal impurities. The nitric acid concentration was calculated by taking into account the dilution of the $1 \mathrm{M}$ concentration in the simulated solution by the oxalic acid addition. Tables 6-10 summarize the elemental concentrations measured in the supernate, wash solutions, and dissolved melter feed. In general, the concentration for each element is the average of four independent samples analyzed by Inductively-Coupled Plasma Emission Spectroscopy (ICP-ES).

\section{Solubility of Lanthanide and Metal Impurities}

As expected, the solubility of the lanthanides increase with decreasing excess oxalic acid in the supernate. The solubility of lanthanum, cerium, praseodymium, neodymium, and europium are plotted on Figure 4 as a function of the excess oxalic and nitric acids. Complete curves for samarium and gadolinium were not plotted since the concentrations at high excess oxalic acid were below the ICP-ES detection limits. From the data at low excess oxalic acid, one would expect the solubility curves for samarium and gadolinium to fall just above and below the solubility curve for europium. The extremely low solubility of the lanthanides at high excess oxalic acid concentrations is consistent with the literature where oxalate precipitation from dilute nitric acid solution is reported as a quantitative and fairly specific separation procedure for the lanthanides, which can be determined gravimetrically, with subsequent ignition to the oxides. ${ }^{4}$

The solubility of americium, curium, and plutonium (IV) oxalates under the conditions expected during the pretreatment operations is well documented in the literature. ${ }^{5}$ The solubility data for the three actinides are plotted on Figures 5-7. From the data, it can be seen that the solubilities in $0.3 \mathrm{M}$ excess oxalic acid (with the nitric acid concentration adjusted to less than $1 \mathrm{M}$ ) are less than $10 \mu \mathrm{g} / \mathrm{ml}$ for the $\mathrm{Am} / \mathrm{Cm}$ and approximately $100 \mu \mathrm{g} / \mathrm{ml}$ for plutonium (IV). Therefore, the oxalate precipitation will provide a slight separation of the plutonium from the $\mathrm{Am} / \mathrm{Cm}$ and minimal $\mathrm{Am} / \mathrm{Cm}$ losses.

The concentrations of the metal impurities measured in the oxalate precipitation supernate indicate aluminum, calcium, iron, potassium, manganese, sodium, and nickel are almost completely soluble under the experimental conditions investigated. As a comparison, the concentrations of each element were calculated using the measured concentration in the simulated solution and the dilution provided by the oxalic acid addition. The predicted concentrations, listed in Tables 6-10, are in good agreement with the analyzed supernate concentrations. In addition, the stability constants for all non-alkali elements predict the formation of soluble oxalate complexes (see Table 11$){ }^{6}$ A strong complex is not predicted for potassium, presumably due to steric hindrance which prohibits the relatively large metal ion from 
fitting into the cavity (or cavities) provided by the oxalate ligand. ${ }^{4}$ Literature data for sodium is unavailable. However, the solubilities of sodium oxalate and potassium oxalate monohydrate in water (at $20^{\circ} \mathrm{C}$ ) are given in the literature as 34 and 360 grams/liter, respectively. ${ }^{7}$ Both concentrations are well above concentrations in Tank 17.1 (see Table 1) and the solubility in a $1 \mathrm{M}$ nitric acid solution should be even greater due to the suppression of the free oxalate concentration by the disassociation of the stronger nitric acid.

The presence of chromium in Tank 17.1 was not simulated due to the generation of hazardous waste solutions. However, the aqueous chemistry of chromium (III) should be similar to other elements in the first transition series with the same oxiadation state such as iron and manganese (III). From a comparison of the stability constants for iron and manganese (III) (given as approximately $10^{18}$ in Table 11 for the trioxalato complexes), one would expect a stability constant of similar magnitude for chromium (III). In addition, qualitative information in the literature indicates chromium (III) oxalate is soluble in water, ${ }^{7,8}$ and should be even more soluble in dilute nitric acid. This provides strong evidence that chromium will remain soluble during the in-tank processing.

If the concentrations of aluminum and transition metal impurities are increased by evaporation, the strong complexation reactions with oxalic acid have the potential to increase the solubility of the actinides and generate higher losses during oxalate precipitation. During the scouting experiments used to develop the methodology to measure the specific volume of the oxalate slurry, the concentrations of all elements in the simulated solution were initially increased (simulating evaporation) to generate a larger, more easily measured volume of precipitate. Elemental analyses of the oxalate precipitation supernate (see Table 12) showed an increasing solubility of the lanthanide elements with increasing concentration of the metal impurities. The same effect on the $\mathrm{Am} / \mathrm{Cm}$ solubility would also be expected. This observation is illustrated on Figure 8 by plotting lanthanide solubility as a function of the iron concentration. A complete curve for samarium was not generated since the concentration at low iron was below the ICP-ES detection limits. However, the data at higher iron concentrations indicate the curve would fall between praseodymium and europium. Comparison of Figure 8 with the lanthanide solubility curves (Figure 4) shows the order of the curves are generally the same. The crossover of the neodymium curve is more pronounced on Figure 8, presumably due to the high degree of complexation and the resulting decrease in the effective excess oxalic acid concentration. It also appears some time is required for the system to reach equilibrium due to competition between oxalate complexation and lanthanide precipitation. In experiment ACP-12, which contained the highest impurity concentrations, additional material precipitated in the graduated cylinder used to perform the experiment and supernate samples while the solutions were stored overnight.

\section{Supernate Wash Model}

Since the metal impurities in the Tank 17.1 solution will remain almost completely soluble after the addition of oxalic acid, a large fraction of the unwanted material can be removed by decanting followed by a series of oxalic/nitric acid washes. The measured concentration of these 
elements as a function of 5 sequential $0.25 \mathrm{M}$ oxalic acid/0.5M nitric acid washes is shown for experiments ACP-6, ACP-7, ACP-8, and ACP-10 in Table 6-8, and 10, respectively. The measured concentrations closely agree with the concentrations calculated from a supernate wash model (see equation (1)) derived from a generalized material balance which assumes complete solubility.

$$
C_{N_{i}}=C_{s_{i}}\left(\frac{V_{s}-V_{R}}{V_{W}-V_{s}-V_{R}}\right)^{N}
$$

where: $\mathrm{C}_{\mathrm{N}_{\mathrm{i}}} \equiv$ concentration of ith species after $\mathrm{N}$ wash cycles

$\mathrm{Cs}_{\mathbf{i}} \equiv$ solubility of ith species in the supernate

$\mathrm{Vs} \equiv$ volume of supernate

$V_{R} \equiv$ volume of supernate removed before the first wash

$\mathrm{V}_{\mathrm{W}} \equiv$ volume of wash solution

The model also assumes the volume of wash solution ( $\mathrm{Vw}$ ) and the volume of solution removed after each wash are equal and the volume is the same for all wash cycles.

For illustration purposes, the measured and predicted concentration of iron, aluminum, and sodium (the most abundant metal impurities in Tank 17.1) are plotted as a function of the wash number on Figures 9-11. The predicted values are shown as a continuous line for clarity. Equation (1) may also be used to calculate the concentration of uranium as a function of the number of wash cycles given the concentration in the oxalate precipitation supernate.

\section{Dissolved Melter Feed}

The concentrations of the lanthanides and metal impurities in the dissolved melter feed were calculated by accounting for dilution after the $250 \mathrm{ml}$ aliquot of concentrated (15.7M) nitric acid was added to dissolve the precipitate slurry remaining after the fifth wash cycle (see Tables 6-8 and 10). The lanthanide concentrations were calculated by using the concentrations in the simulated solution and assuming no losses. The percent recovery was then calculated from the ratio of the analyzed to the calculated concentration. Except for lanthanum, the recovery of the lanthanide elements was greater than $95 \%$ for excess oxalic acid concentrations of $0.3 \mathrm{M}$ or greater. From the low solubilities of $\mathrm{Am} / \mathrm{Cm}$ (see Figures 5 and 6 ), one would also expect theoretical recoveries approaching $100 \%$.

The concentrations of the metal impurities predicted from equation (1) after the fifth wash cycle were used to calculate the melter feed concentrations given in Tables 6-8 and 10. Good agreement between the calculated and measured concentrations provide confirmation that these elements are almost completely soluble under the conditions investigated. 


\section{Properties of Precipitate Slurry}

Initially, three small-scale scouting experiments were performed to gain experience and develop the methodology required to make an accurate measurement of the specific volume of the oxalate slurry. The experiments were designed based on the measured specific volume of the simulated $\mathrm{Am} / \mathrm{Cm}$ surrogate (3.6 liters/mole of simulant) reported by Gray et al. ${ }^{1}$ and the use of the $120-\mathrm{mm}$ diameter glass precipitator. The concentrations of all elements in the simulated solution were initially increased (simulating evaporation) to generate a larger, more easily measured volume of precipitate. The simulated solutions were prepared to generate 6 (ACP-11) and 9-inch (ACP-12 and ACP-13) slurry layers on the bottom of the large precipitator. The specific volumes measured during these experiments ranged between 0.5 and 0.7 liters $/ \mathrm{mole}$ of lanthanides, compared to the previously reported value of 3.6. The large difference in specific volumes is likely due to a high concentration and subsequent precipitation of sodium from the simulated solution used by the previous investigators. The results from the small-scale experiments are summarized in Table 13.

Once the deleterious effect of high concentrations of aluminum and transition metal impurities on the oxalate precipitation were seen and resolved in experiment ACP-13, a large-scale precipitation was performed using the $120-\mathrm{mm}$ diameter glass precipitator. The target concentrations of the simulated solution for this experiment (ACP-14) were the same as prepared for experiment ACP-13. The concentrations of the metal impurities in the simulant were held at approximately the same concentrations as in Tank 17.1 while the lanthanide concentrations were increased by a factor of approximately 8.5 . Using this solution, the specific volume of the oxalate precipitate slurry was found to be 0.5 liters per mole of lanthanide/actinide simulant. The precipitations were performed at $60^{\circ} \mathrm{C}$ using a $0.9 \mathrm{M}$ solution of oxalic acid. The excess oxalic acid concentration was adjusted to $0.3 \mathrm{M}$. The results of the specific volume measurement and elemental concentrations in the precipitation supernate are summarized in Tables 13 and 14, respectively.

When the precipitator stirrer was stopped, most of the precipitate settled in a few minutes. The supernate was clear of all but the smallest particles after 30 minutes. Typical particle settling rates observed were on the order of $30 \mathrm{~cm} / \mathrm{min}$. The build-up of precipitate on the top edge of the stirrer blades also demonstrated that the precipitate will settle on any horizontal surfaces in a canyon tank such as cooling coils and agitator blades. This has the potential to lead to high $\mathrm{Am} / \mathrm{Cm}$ losses during in-tank processing when solution is removed from the tank.

It should also be noted that the settling behavior of the simulated oxalate precipitate may not be entirely typical of the settling rate in Tank 17.1. The presence of high alpha radiation (primarily from curium-244) in the tank may have an effect on the settling rate. Alpha radiation will cause the breakup of curium-containing particles, possible creating fines that do not settle as rapidly as most of the oxalates seen in the simulated precipitation. The slow settling fines may be a better model for the curium oxalate. 
Once the precipitate settles to the bottom of the tank, the suction from the steam jet should not disturb the precipitate. A dip tube placed 1-inch from the top of the oxalate slurry did not disturb the precipitate during removal of supernate from the precipitator. The measured velocity of the solution through the tube, based on volume and time, was approximately $560 \mathrm{ft} / \mathrm{min}$. This value is well above the maximum velocity of typical canyon steam jets. F-Canyon normally uses two standard jets for solution transfers: a $75 \mathrm{gal} / \mathrm{min}$ jet with a linear face velocity of $460 \mathrm{ft} / \mathrm{min}$ and a $25 \mathrm{gal} / \mathrm{min}$ jet with a linear face velocity of $155 \mathrm{ft} / \mathrm{min} .^{1}$

\section{Conclusions and Recommendations}

The small-scale experiments demonstrated that uranium and metal impurities in Tank 17.1 will remain soluble during in-tank processing. The majority of the lanthanides and plutonium and essentially all of the $\mathrm{Am} / \mathrm{Cm}$ will be isolated as a precipitate slurry during the oxalate precipitation. Optimal precipitation conditions include adjusting the nitric acid concentration to less than $1 \mathrm{M}$, heating the solution to $60^{\circ} \mathrm{C}$, adding the oxalic acid precipitate (over a 15 to 30 minute period with agitation) until an excess of $0.3 \mathrm{M}$ is reached, and holding the solution at $45^{\circ} \mathrm{C}$ during a 4 hour digestion period. Although, the majority of the precipitate settled in only a few minutes during the laboratory experiments, a minimum of 8 hours should be used during processing of the Tank 17.1 material to insure complete settling of potential curium oxalate fines. The solution temperature should not exceed $35^{\circ} \mathrm{C}$ during the settling period (and subsequent wash cycles).

Once the precipitation is complete, unwanted, soluble materials, such as uranium, iron, aluminum, and sodium can be removed by decanting and a series of $0.25 \mathrm{M}$ oxalic acid/ $0.5 \mathrm{M}$ nitric acid washes. The amount of impurities removed during the wash are only functions of the volume and number of wash cycles. Larger volumes of oxalic acid or wash solution will reduce the number of wash cycles required to achieve a specified separation. The removal of specific elements during the precipitation and wash cycles can be predicted by assuming complete solubility and taking into account the dilution provided by the oxalic acid precipitate or wash solution.

Although the concentration of the actinides in Tank 17.1 are dilute, significant evaporation of the solution should not be attempted. Higher concentrations of the soluble elements such as iron aluminum, and uranium which form strong oxalate complexes, will increase the solubility of the $\mathrm{Am} / \mathrm{Cm}$ by reducing the effective excess free oxalate concentration. Compensation for a high degree of complexation can be provided by adding additional oxalic acid during the precipitation; however, the exact requirements would require additional development work to define the optimal concentration and measurement of the new precipitate slurry properties.

Using approximately 2 liters of simulated Tank 17.1 solution, the specific volume of the oxalate slurry was found to be 0.5 liters per mole of lanthanide/actinide simulant. When the precipitator stirrer was stopped, most of the precipitate settled in only a few minutes. The supernate was 
clear of all but the smallest particles after 30 minutes. The experiment also demonstrated that the precipitate will settle on any horizontal surfaces in a canyon tank such as cooling coils and agitator blades. However, once settled to the bottom of the tank, the suction from a steam jet should not disturb the precipitate. A dip tube placed 1-inch from the top of the oxalate slurry did not disturb the precipitate during removal of supernate from the precipitator. The measured velocity of the solution was well above the maximum velocity of typical canyon steam jets.

During the original separation of the $\mathrm{Am} / \mathrm{Cm}$ contained in Tank 17.1 from the aluminum nitrate-containing waste solution, the decanting losses were much higher than anticipated. A total of about $20 \%$ of the product was entrained to the waste evaporator with the decanted supernate. The high losses were attributed to the solids, particularly those settled on the coils and agitator blades, being disturbed prior to and during the transfer of solution. A new decant jet, with a plate welded across the bottom and holes drilled around the pipe above the plate to provide horizontal rather than vertical suction, was used without success to lower the transfer losses. ${ }^{7}$ From this information, it appears the transfer losses can be reduced by minimizing the number of supernate transfers. This can be accomplished by reducing the concentration of the oxalic acid precipitant and using a larger volume to adjust the excess concentration to $0.3 \mathrm{M}$. The larger volume of solution will allow more of the uranium and metal impurities to be removed during the supernate transfer. Performing the precipitation in this manner coupled with the use of the maximum volume of wash solution (which can be accommodated by the processing tank) will minimize the number of wash cycles and solution transfers required to achieve a specified separation.

Alternately, a process strategy could be developed to perform the in-tank precipitation and subsequent washes without bringing the solution level below the coils or agitator blades. If the tip of the transfer jet is above the coils, the potential for entrainment is minimized; however, the number of washes required to remove a sepecified amount of uranium and metal impurities increases. A solution level between 4 and 5 feet would be required in an 8-ft (diameter) X 11-ft (tall) tank to cover the coils. This would leave between 50 and $60 \%$ of the working volume available for the wash solution.

If turbulence in the tank and entrainment of solids due to the steam jet operation is the principal cause of $\mathrm{Am} / \mathrm{Cm}$ losses, alternatives to steam jets for solution transfer exist. Air lifts have been used successfully in the canyons for frame operation to transfer solution from tanks to ion exchange columns. Flow rates in the range of $10 \mathrm{gal} / \mathrm{min}$ are typical. This compares to 25 $\mathrm{gal} / \mathrm{min}$ for a low flow steam jet. This provides another option for consideration if high losses of $\mathrm{Am} / \mathrm{Cm}$ cannot be recycled or discarded to waste. 


\section{References}

1. L. W. Gray, G. A. Burney, T. W. Wilson, and J. M. McKibben. Separation of Am-Cm from $\mathrm{NaNO}_{3}$ Waste Solutions by In-Canyon-Tank Precipitation as Oxalates (U). External Report DP-1539. E. I. du Pont de Nemours \& Co., Savannah River Laboratory, Aiken, SC (September 1981).

2. L. W. Gray, G. A. Burney, T. W. Wilson, and J. M. McKibben, N. E. Bibler, E. W. Holtzscheiter, and T. G. Campbell. Separation of Am-Cm from Al( $\left.\mathrm{NO}_{3}\right)_{3}$ Waste Solutions by In-Canyon-Tank Precipitation as Oxalates $(U)$. External Report DP-1572. E. I. du Pont de Nemours \& Co., Savannah River Laboratory, Aiken, SC (April 1982).

3. J. J. Katz, G. T. Seaborg, and L. R. Morss, Editors. The Chemistry of the Actinide Elements, Second Edition. Chapman and Hall, New York, NY (1986).

4. F. A. Cotton and G. Wilkinson. Advanced Inorganic Chemistry, Fifth Edition. John Wiley \& Sons, New York, NY (1988).

5. L. Gmelin. Gmelin Handbuch der Anorganischen Chemie. Band 20, Teil D1: Chemie in Lösung. Springer-Veriag, New York, NY (1975).

6. A. E. Martell and R. M. Smith. Critical Stability Constants, Volume 3: Other Organic Ligands. Plenum Press, New York, NY (1977).

7. J. A. Dean, Editor. Lange's Handbook of Chemistry, 13th Edition. McGraw-Hill Book Company, New York, NY (1985).

8. R. C. Weast, Editor. Handbook of Chemistry and Physics, 56th Edition. CRC Press, Cleveland, $\mathrm{OH}$ (1975). 
Figure $1 \mathrm{Am} / \mathrm{Cm}$ Purification in F-Canyon

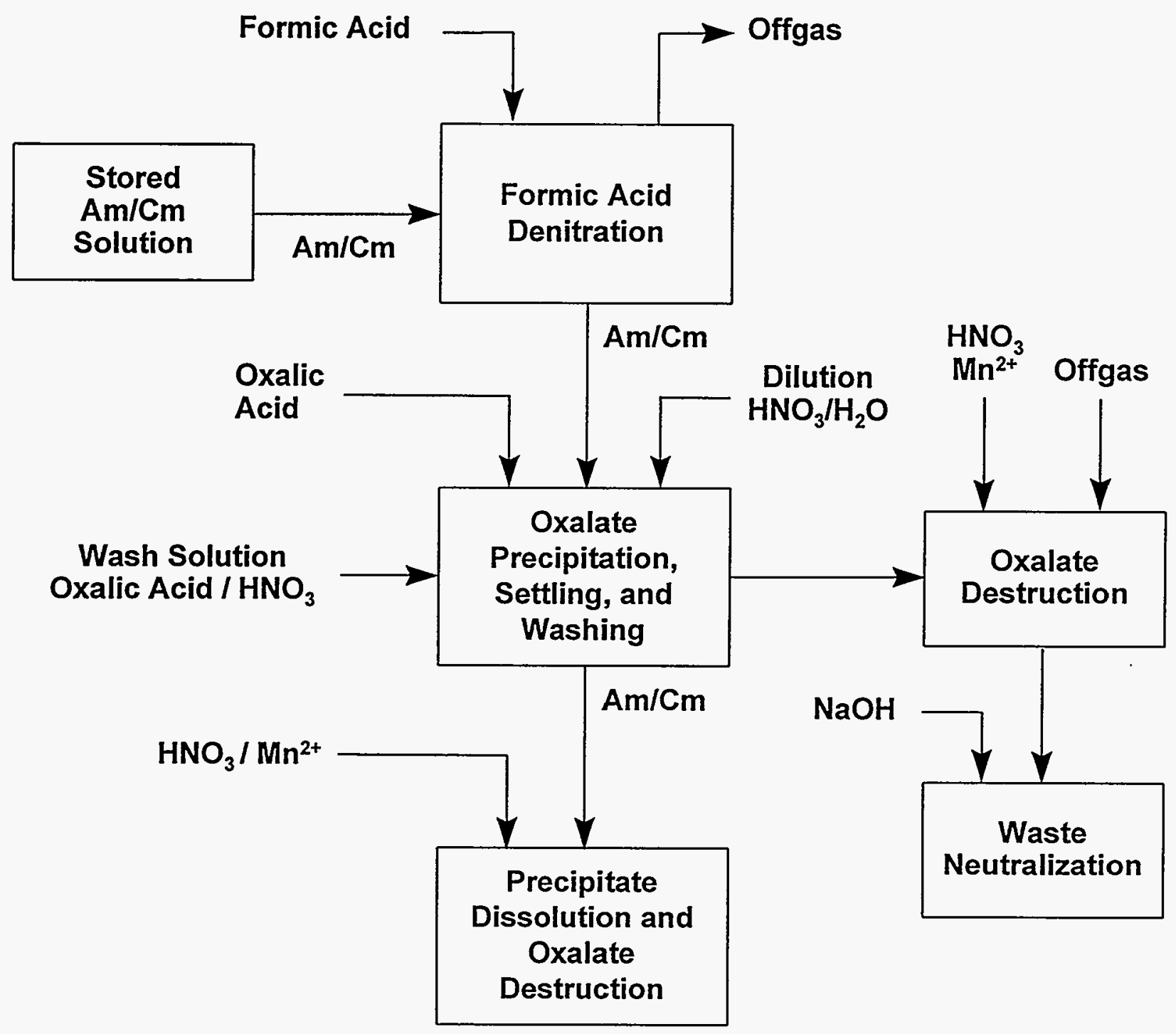


Figure 2 Small-scale Precipitation Equipment

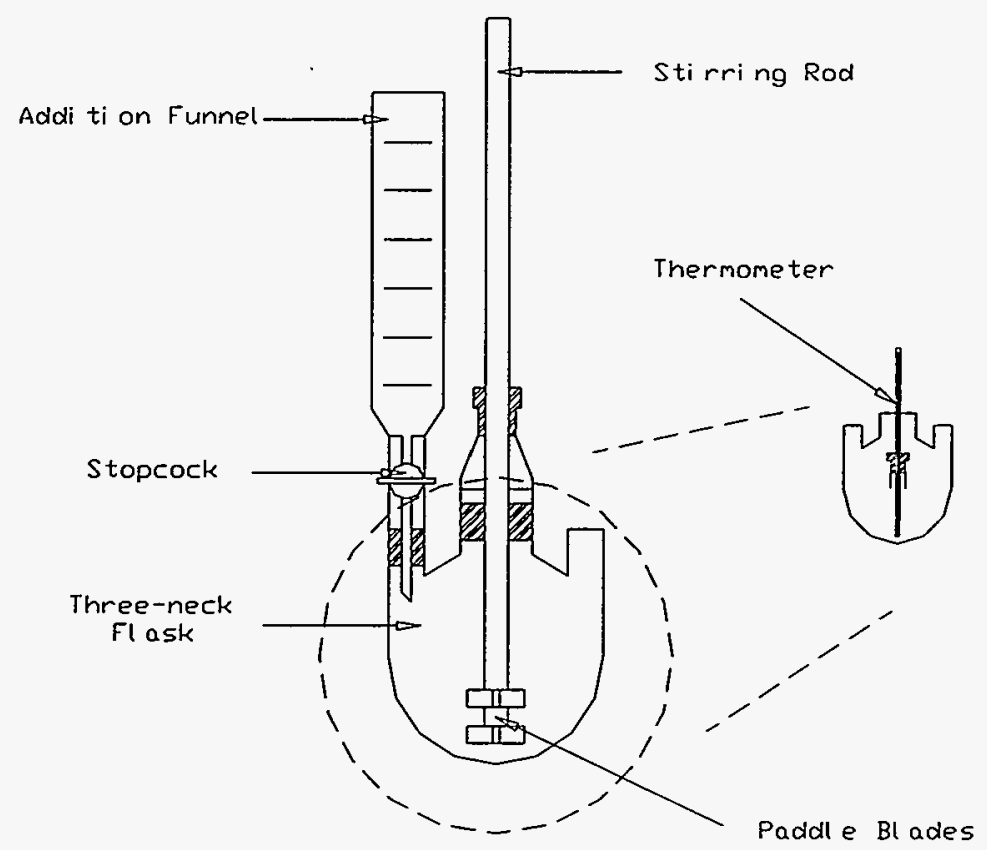

Precipitation Vessel

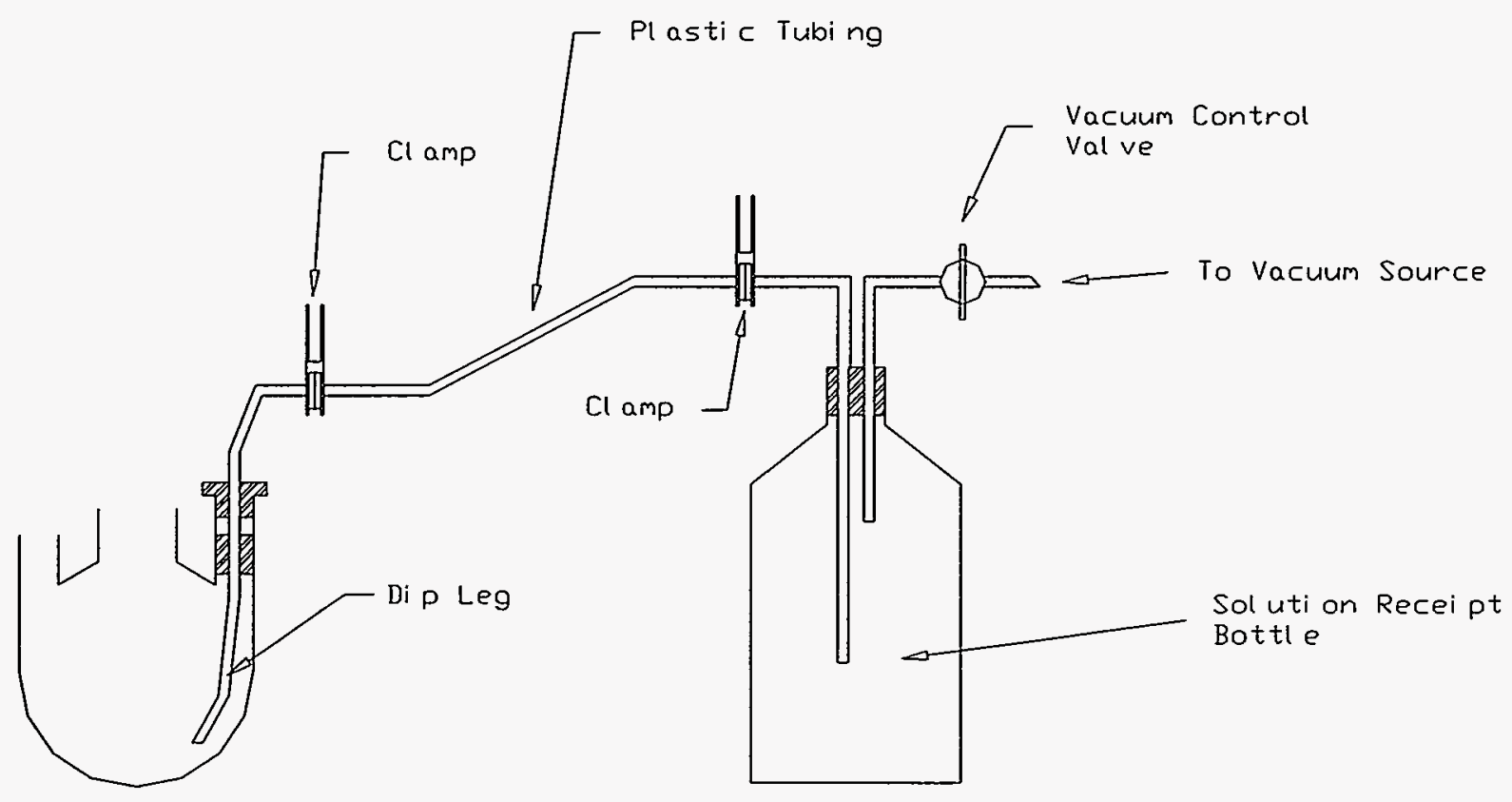

Solution Transfer Equipment 
Figure 3 Large-scale Precipitation Equipment

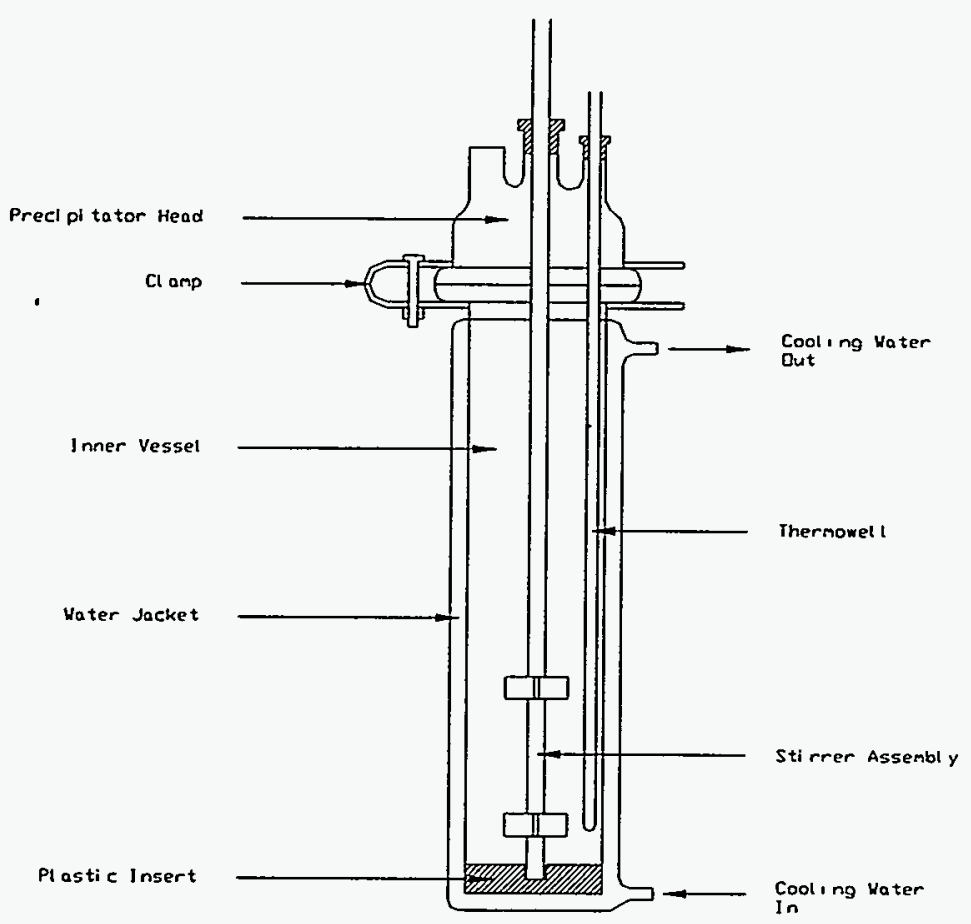

Precipitator

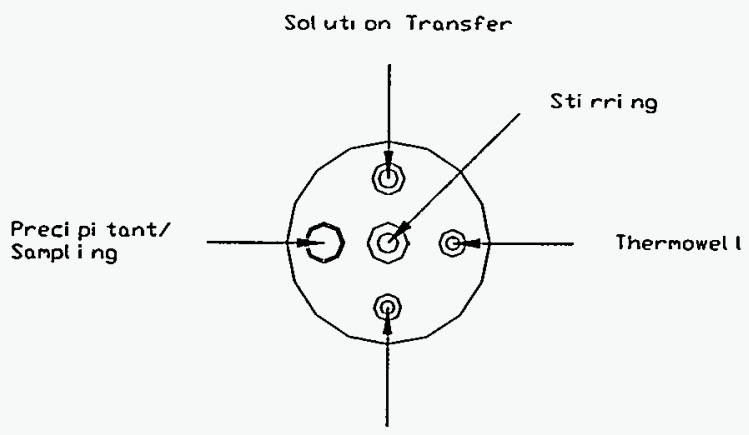

Thermoneter

Precipitator Head 
Figure 4 Solubility of Lanthanide Oxalates

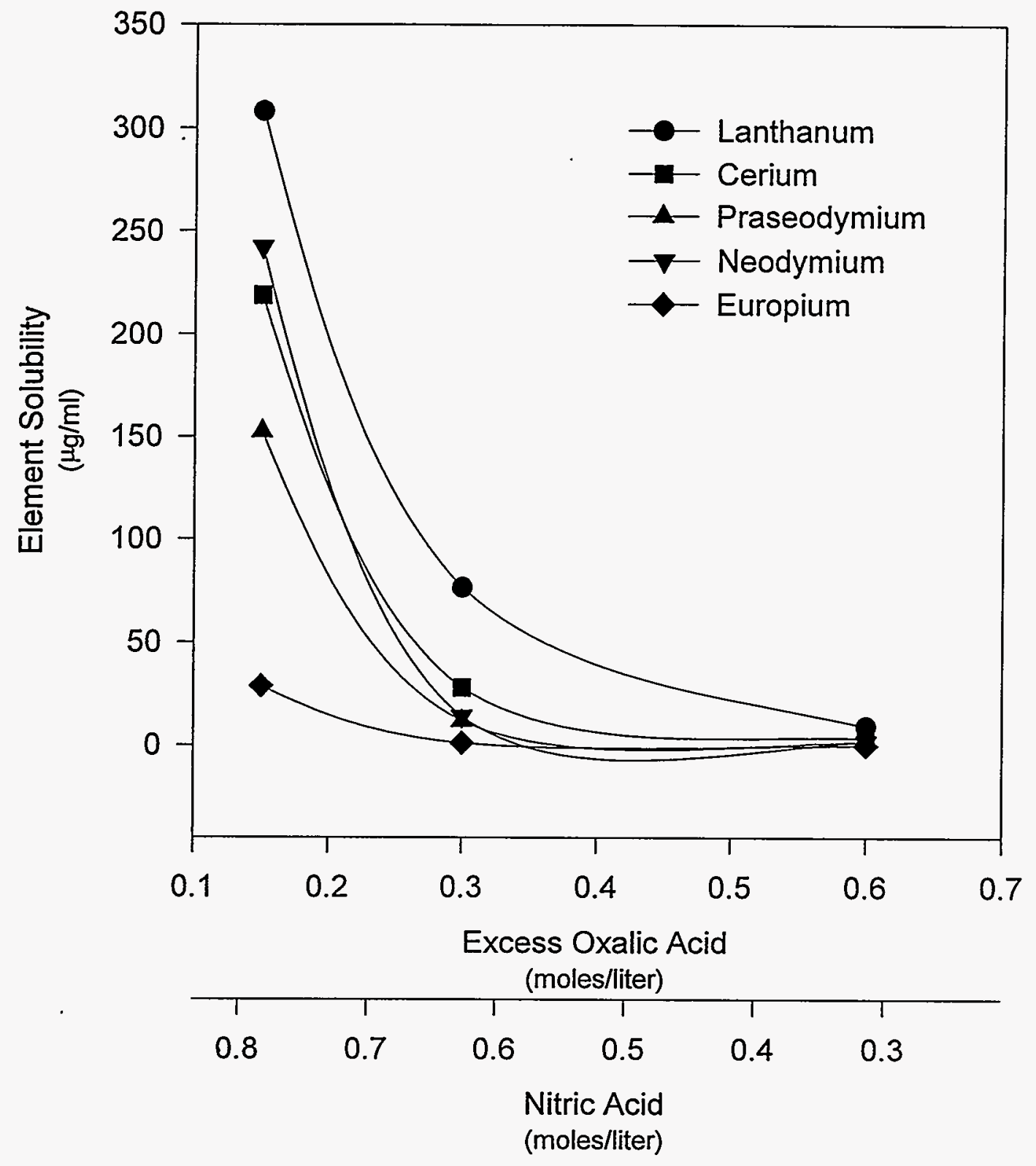


Figure 5 Solubility of Americium (III) Oxalate

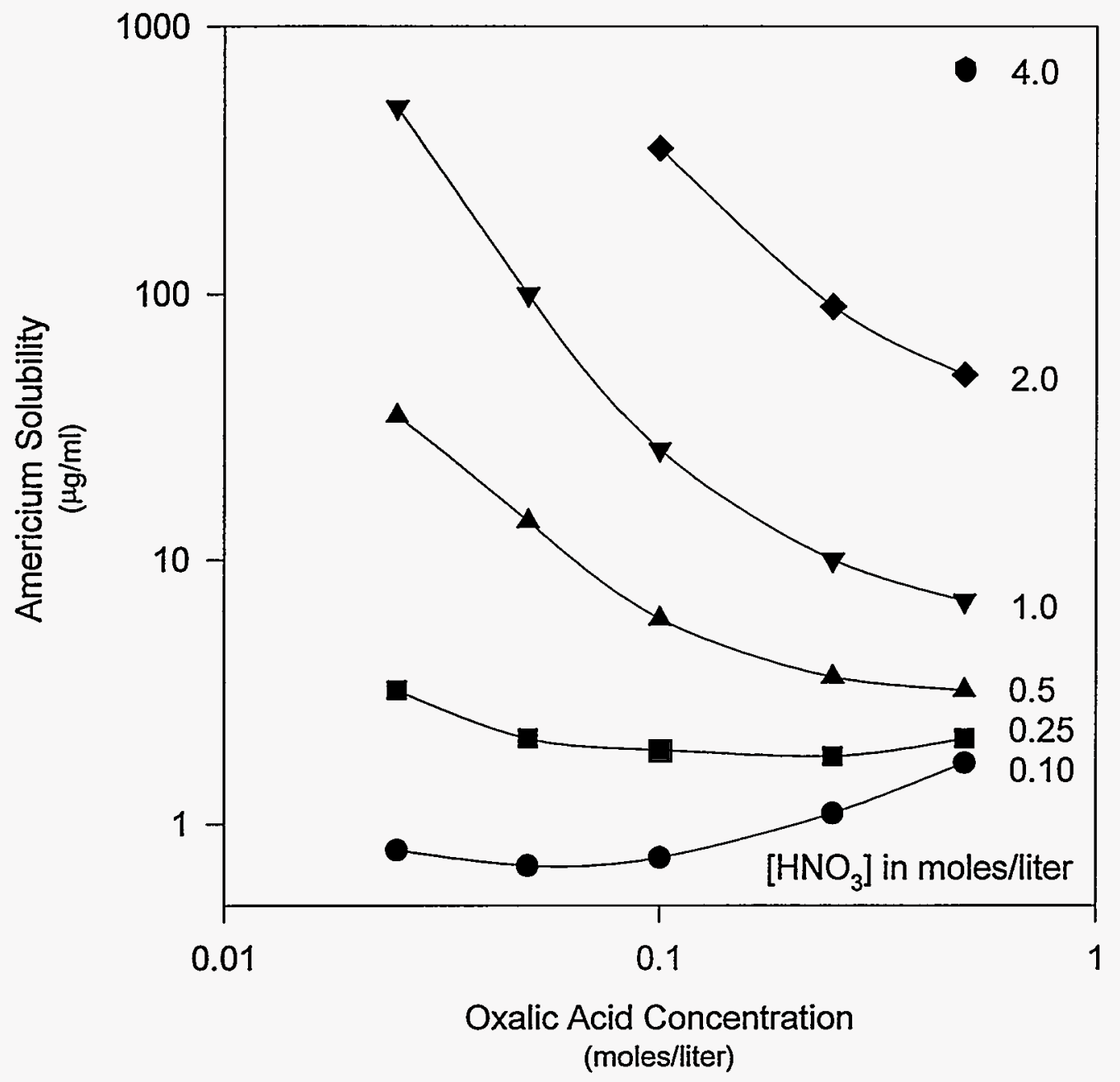


Figure 6 Solubility of Curium (III) Oxalate

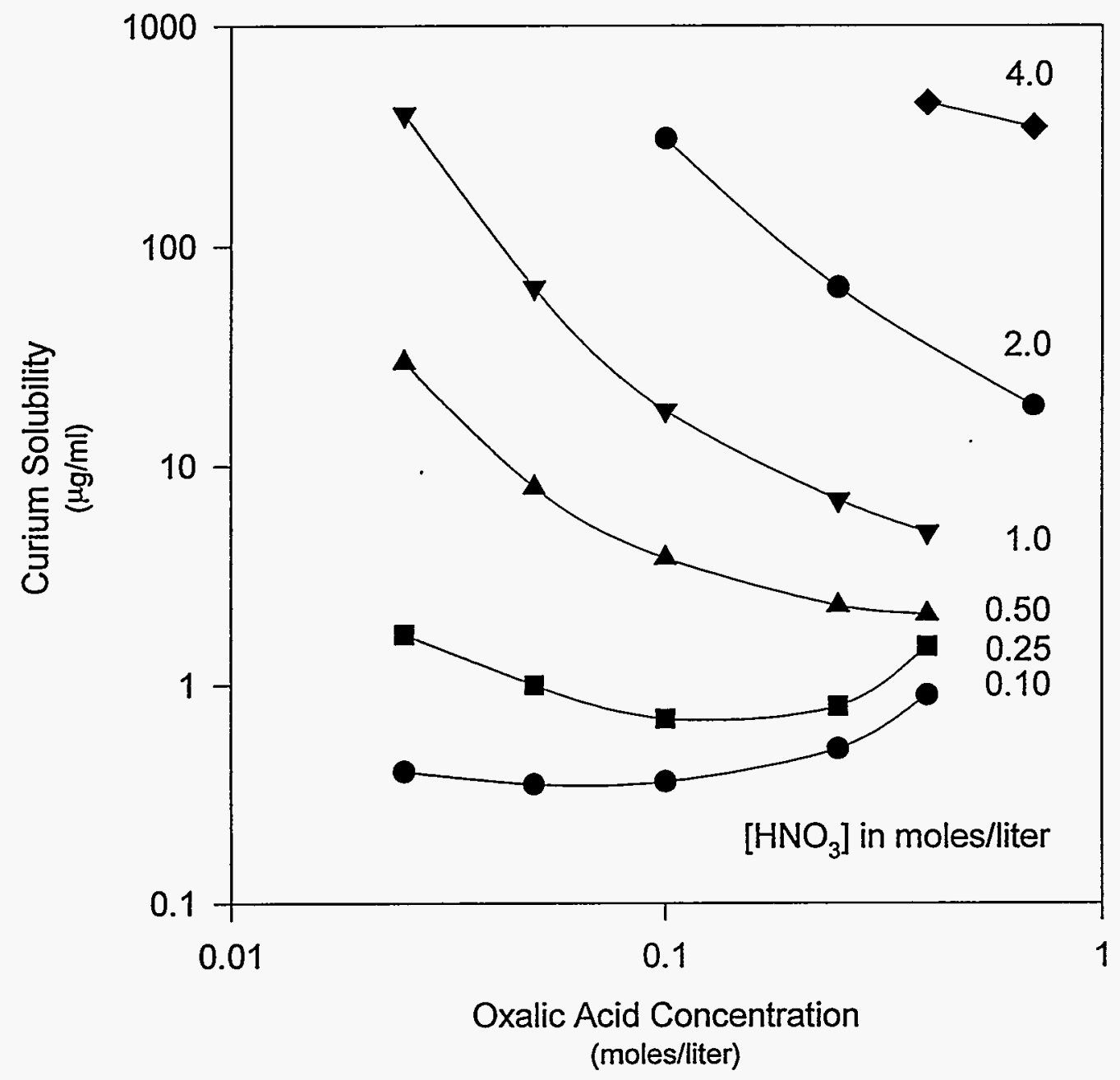


Figure 7 Solubility of Plutonium (IV) Oxalate

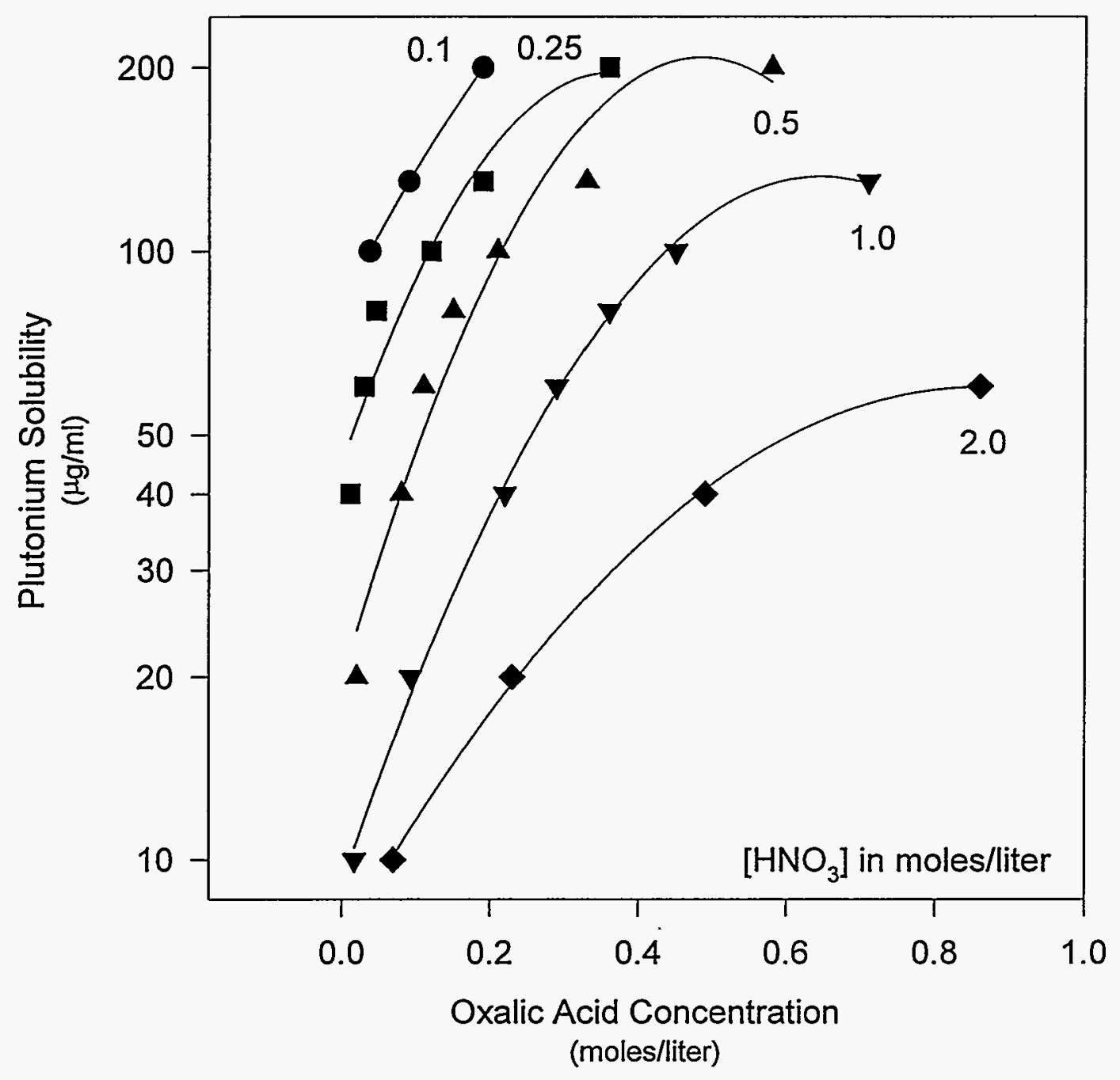


Figure 8 Effect of Iron on the Solubility of Lanthanide Oxalates

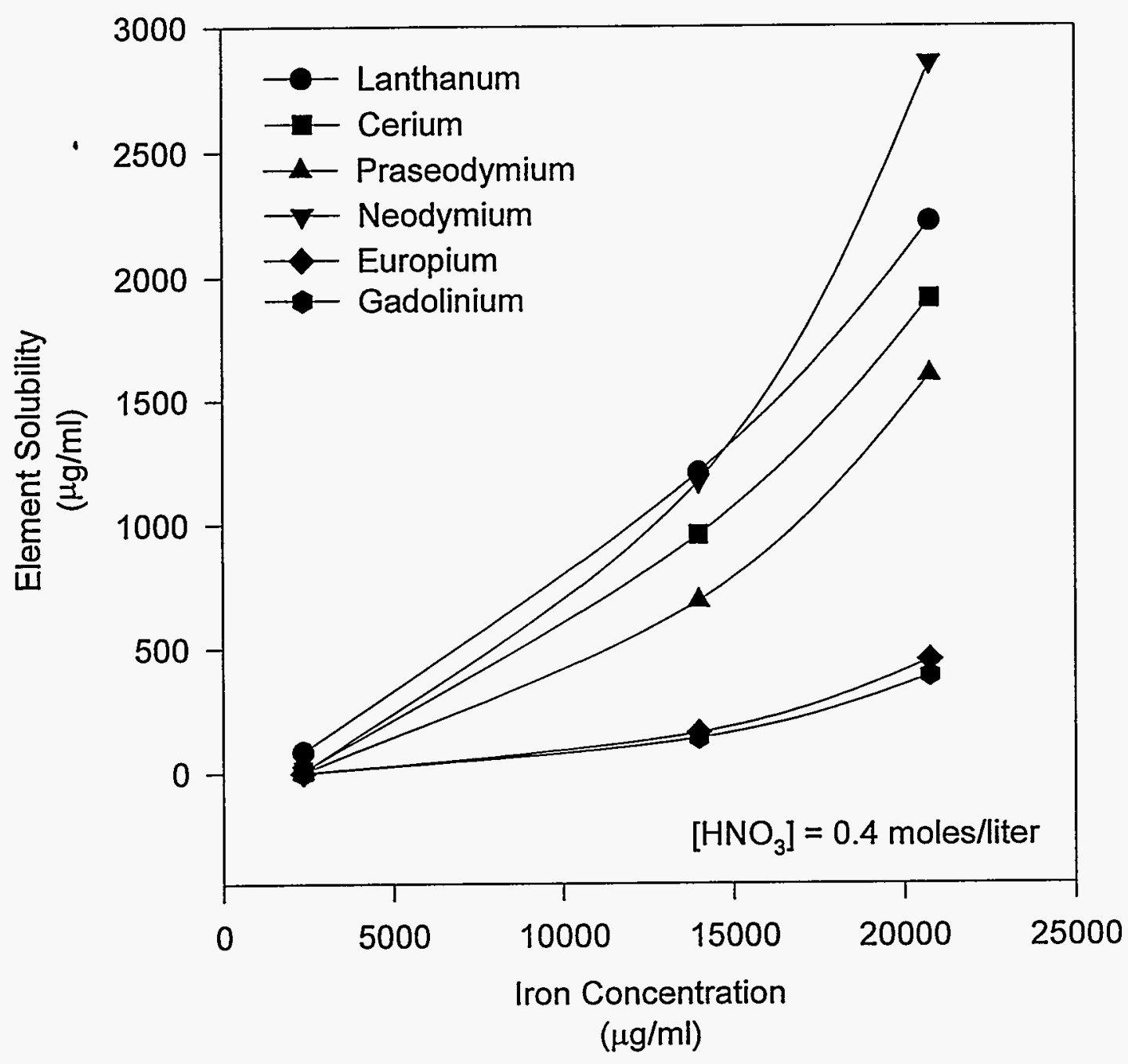


Figure 9 Removal of Iron from Oxalate Precipitation Supernate

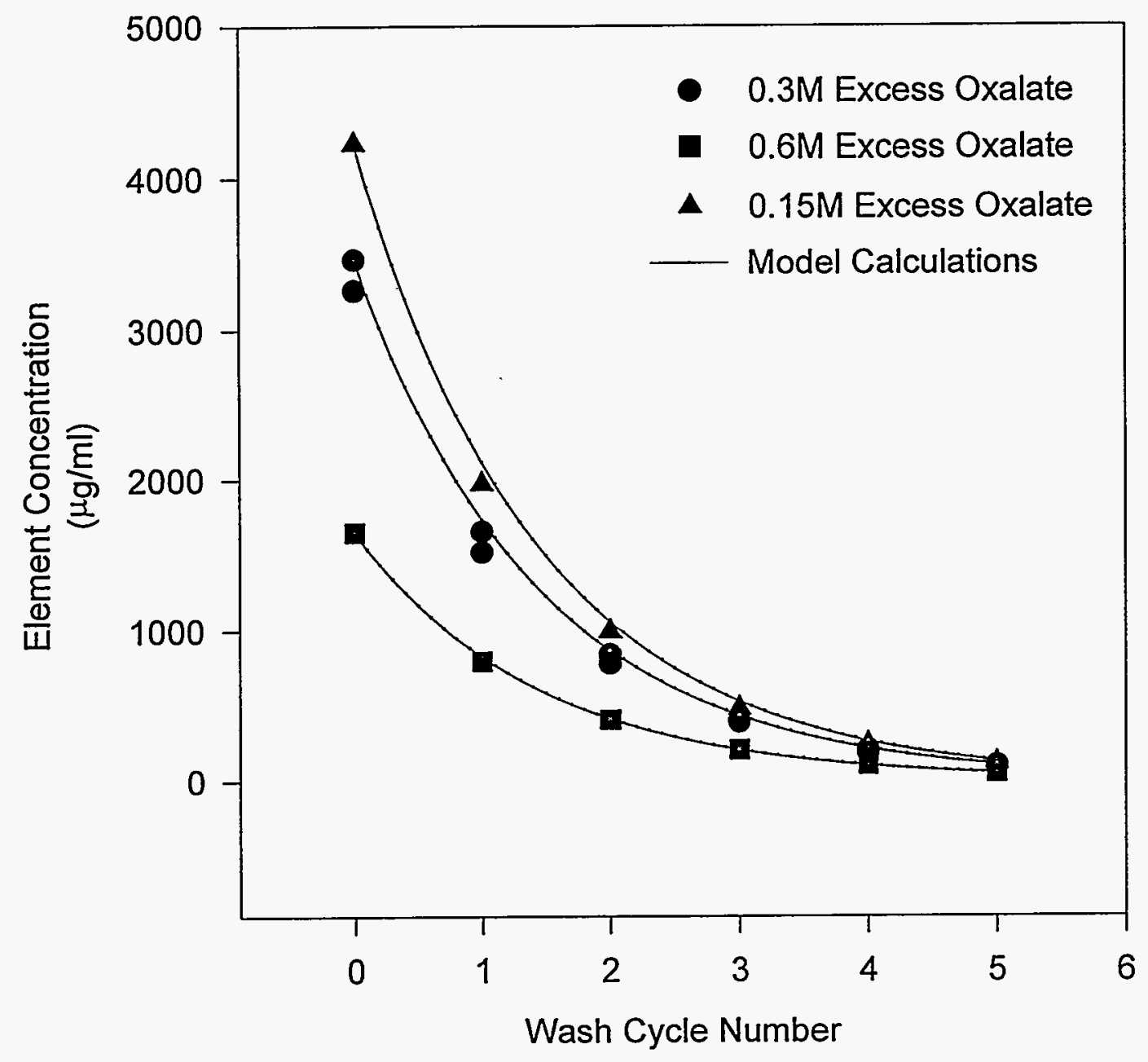


Figure 10 Removal of Aluminum from Oxalate Precipitation Supernate

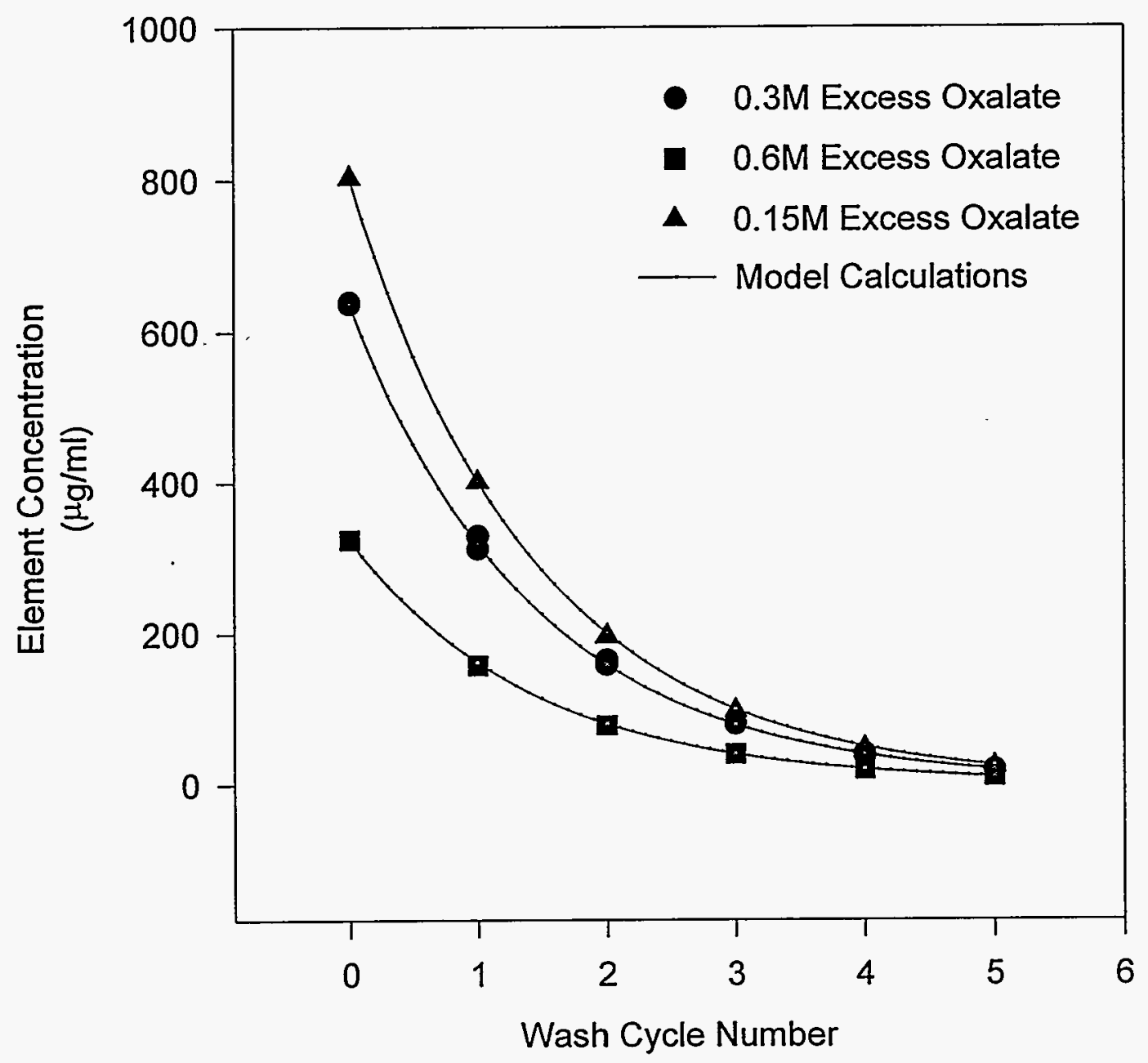


Figure 11 Removal of Sodium from Oxalate Precipitation Supernate

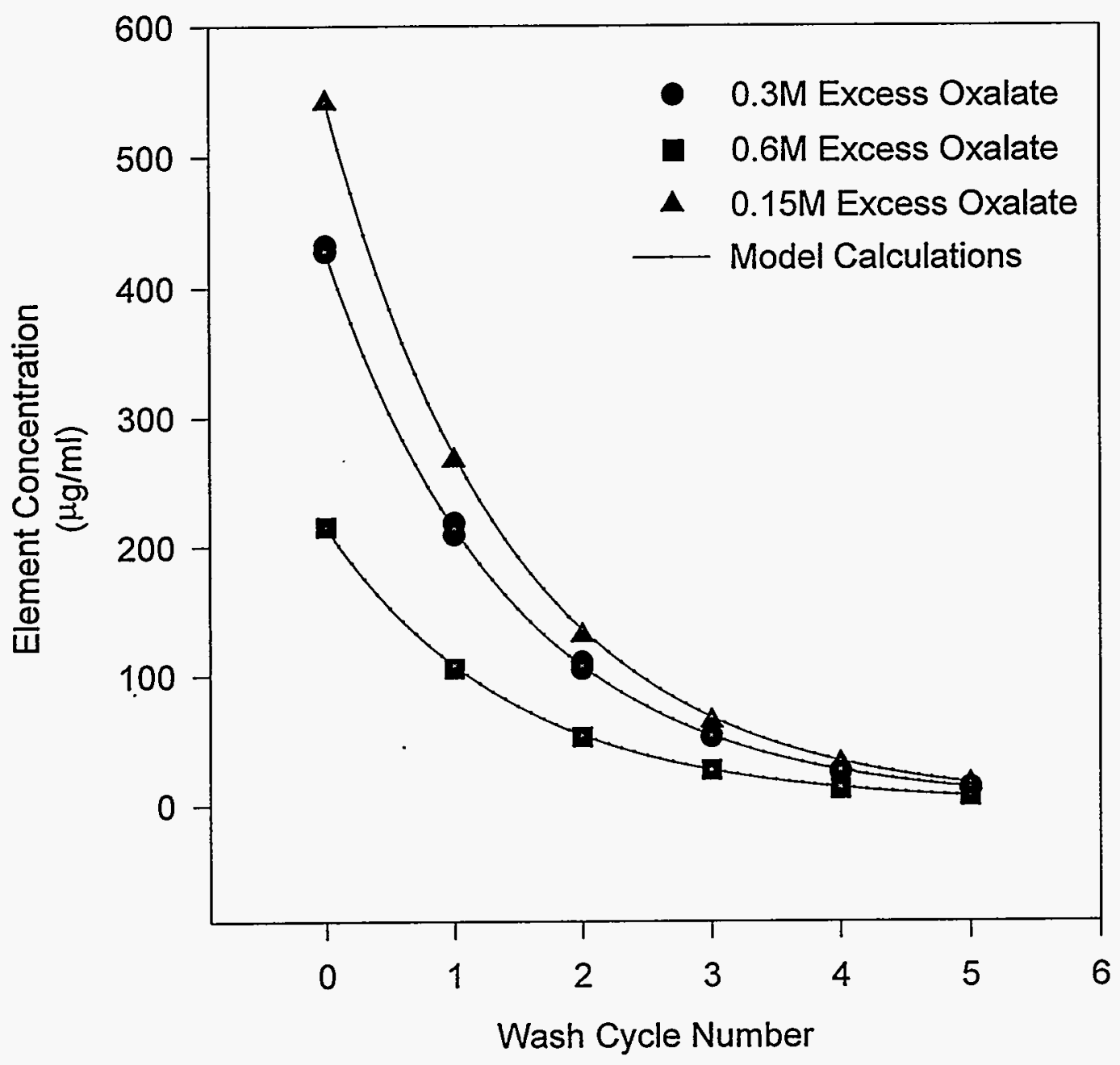


Table 1 Chemical Analysis of Tank 17.1 Solution

Lanthanides

La

$\mathrm{Ce}$

$\operatorname{Pr}$

$\mathrm{Nd}$

$\mathrm{Sm}$

$\mathrm{Eu}$

$\mathrm{Gd}$

$\mathrm{Tb}$

Dy

Ho

$\mathrm{Er}$

$\mathrm{Tm}$

$\mathrm{Yb}$

$\mathrm{Lu}$

Element

Total U

Total Pu

Total Am

Total $\mathrm{Cm}$

Lanthanides and Miscellaneous Metals

Grams

10,598

12,112

12,112

25,738

1,211

3,028

$<454$

$<454$

$<454$

$<454$

$<606$

$<454$

$<454$
6,056

Element

$\mathrm{Al}$

B

$\mathrm{Ca}$

$\mathrm{Cr}$

$\mathrm{Fe}$

$\mathrm{K}$

$\mathrm{Mn}$

$\mathrm{Na}$

$\mathrm{Ni}$

$\mathrm{Si}$

$\mathrm{Zn}$

$\mathrm{Zr}$

Actinides

Grams

9387

2471

10159

2740
Al

a

4,330

74,943

$<3255$

3,588

10,174

3,452

273

318

61
Wt. \%

0.204

0.198

0.037

99.562

U-238

Pu-238

Pu-239

Pu-240

$\mathrm{Pu}-241$

$\mathrm{Pu}-242$

Am-241

Am-242m

Am-243

Cm-244

$\mathrm{Cm}-245$

Cm-246

Cm-247
5.832

2.494

86.636

0.058

4.981

4.51

0.02

95.47

93.27

3.57

3.11

0.05 
Table 2 Operating Limits for Am/Cm Purification in F-Canyon

\section{Denitration}

Evaporator Solution
1. Volume
2. Temperature
3. $\mathrm{HNO}_{3}$ Concentration

Formic Acid Feed

1. Formic Acid Concentration

2. Quantity of Formic Acid Added

3. Addition Rate

4. Temperature in Storage
Min $\quad$ Max

Units
2400

90

0.2

88

1.00

0.5

0 (a) $\quad{ }^{\circ} \mathrm{C}$

$10.0 \quad \mathrm{M}$
$4700 \quad$ liters

\section{Precipitation}

Oxalic Acid Feed Make-up
1. Oxalic Acid Concentration
2. Temperature in Storage

0.8

1.0

$\mathrm{M}$

20

80

$\mathrm{Wt} \%$

(b)

$\mathrm{lb} / \mathrm{min}$

3.2

60

${ }^{\circ} \mathrm{C}$

Oxalic Acid Addition

1. Precipitator Solution Temperature

60

80

${ }^{\circ} \mathrm{C}$

2. $\mathrm{HNO}_{3}$ Concentration (c) Aluminum Concentration Sodium Concentration

$-$

$\begin{array}{lll}- & 0.5 & \mathrm{M}\end{array}$

$\begin{array}{lll}- & 0.5 & \mathrm{M}\end{array}$

Digestion

1. Solution Temperature

2. Time

${ }^{\circ} \mathrm{C}$

4

hours

Settling

1. Solution Temperature

2. Time

$\begin{array}{lll}- & 35 & { }^{\circ} \mathrm{C} \\ 8 & - & \text { hours }\end{array}$

Oxalate Oxidation

1. Manganous Ion Concentration

2. $\mathrm{HNO}_{3}$ Concentration

$\begin{array}{lll}- & 0.02 & \mathrm{M} \\ 1 & 5 & \mathrm{M}\end{array}$


Table 3 Uranium Oxalate Solubility Data

Exp't

ACP-1 Average 567

$95 \% \mathrm{CL} \quad 20$

ACP-2 Average 567

95\% CL $\quad 20$

ACP-3 Average 563

$95 \% \mathrm{CL} \quad 18$

ACP-4 Average 563

$95 \% \mathrm{CL} \quad 18$

ACP-5 Average 563

$95 \% \mathrm{CL}$

\begin{abstract}
$\mathrm{La}$
\end{abstract}
Simulant

$(\mu \mathrm{g} / \mathrm{ml})$
U

Supernate

$(\mu \mathrm{g} / \mathrm{ml})$
U Calc

$(\mu \mathrm{g} / \mathrm{ml})$

\section{La} Supernate

$(\mu \mathrm{g} / \mathrm{ml})$

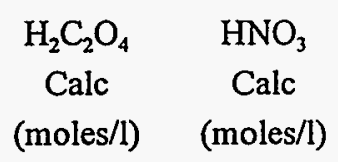

$0.30 \quad 0.67$

$37 \quad 13$

$185 \quad 189$

$\begin{array}{ll}9 & 7\end{array}$

$0.60 \quad 0.33$

$\begin{array}{lll}5117 & 288 & 299\end{array}$

75

8

9

11

0.39

0.53

3

$5117 \quad 330$

75

43

352

11

27

0.30

0.63

2

340

13
352

11

1

25

0.30

0.63

75

1


Table 4 Comparison of Measured and Calculated Uranium Concentrations

$\begin{array}{lcccccccc}\text { Exp't } & \begin{array}{c}\mathrm{U} \\ \begin{array}{c}\text { Supernate } \\ (\mu \mathrm{g} / \mathrm{ml})\end{array}\end{array} & \begin{array}{c}\mathrm{S}_{\mathrm{U}} \\ (\mu \mathrm{g} / \mathrm{ml})\end{array} & \begin{array}{c}\mathrm{U} \\ \mathrm{Calc} \\ (\mu \mathrm{g} / \mathrm{ml})\end{array} & \begin{array}{c}\mathrm{S}_{\mathrm{U}} \\ \mathrm{Calc} \\ (\mu \mathrm{g} / \mathrm{ml})\end{array} & \begin{array}{c}\mathrm{S}_{\text {pooled }} \\ (\mu \mathrm{g} / \mathrm{ml})\end{array} & \mathrm{t}_{\text {calc }} & \begin{array}{c}\text { Degrees } \\ \text { Freedom }\end{array} & \mathrm{t}_{0.025} \\ \mathrm{ACP}-1 & 360 & 35 & 378 & 14 & 26 & 0.699 & 11 & 2.201 \\ \mathrm{ACP}-2 & 185 & 6 & 189 & 7 & 7 & 0.599 & 9 & 2.262 \\ \mathrm{ACP}-3 & 288 & 5 & 299 & 14 & 13 & 0.879 & 13 & 2.160 \\ \text { ACP-4 } & 330 & 27 & 352 & 16 & 19 & 1.151 & 13 & 2.160 \\ \text { ACP-5 } & 340 & 8 & 352 & 16 & 15 & 0.825 & 13 & 2.160\end{array}$


Table 5 Precipitation Conditions for $\mathrm{Am} / \mathrm{Cm}$ Pretreatment Experiments

\begin{tabular}{|c|c|c|c|}
\hline \multirow[t]{2}{*}{ Experiment } & \multicolumn{2}{|c|}{ Final Precipitation Conditions } & \multirow[t]{2}{*}{ No. Wash Cycles } \\
\hline & $\begin{array}{c}\mathrm{H}_{2} \mathrm{C}_{2} \mathrm{O}_{4} \\
\text { (moles } / \text { ) }\end{array}$ & $\begin{array}{c}\mathrm{HNO}_{3} \\
(\text { moles/l) }\end{array}$ & \\
\hline $\mathrm{ACP}-6$ & 0.30 & 0.63 & 5 \\
\hline ACP-7 & 0.60 & 0.31 & 5 \\
\hline ACP-8 & 0.15 & 0.78 & 5 \\
\hline ACP-9 & 0.30 & 0.63 & 0 (a) \\
\hline ACP-10 & 0.30 & 0.63 & 5 \\
\hline
\end{tabular}

(a) The oxalate precipitate was not washed due to problems with the stirrer operation. 
Table 6 Oxalate Solubility Data for Experiment ACP-6

Lanthanides

$\underset{(\mu \mathrm{g} / \mathrm{ml})}{\mathrm{La}} \quad \underset{(\mu \mathrm{g} / \mathrm{ml})}{\mathrm{Ce}} \quad \underset{(\mu \mathrm{g} / \mathrm{ml})}{\mathrm{Pr}} \quad \underset{(\mu \mathrm{g} / \mathrm{ml})}{\mathrm{Nd}} \quad \underset{(\mu \mathrm{g} / \mathrm{ml})}{\mathrm{Sm}} \quad \underset{(\mu \mathrm{g} / \mathrm{ml})}{\mathrm{Eu}} \quad \underset{(\mu \mathrm{g} / \mathrm{ml})}{\mathrm{Gd}}$

\section{Simulant}

Makeup

Analysis

700

807

802

797

1700

1674

502

500

321

522

374

312

Supernate

Analysis

75.6

25.4

10.3

$13.1<2.500$

1.4

1.0

1st Wash

Analysis

30.6

7.1

2.6

$<2.000$

$<2.500$

0.2

$<0.370$

2nd Wash

Analysis

14.4

$<2.800$

$<1.100$

$<2.000$

$<2.500$

$<0.080$

$<0.370$

3rd Wash

Analysis

7.1

$<2.800$

$<1.100$

$<2.000$

$<2.500$

$<0.080$

$<0.370$

4th Wash

Analysis

$$
4.4
$$

$<2.800$

$<1.100$

$<2.000$

$<2.500$

$<0.080$

$<0.370$

5th Wash

Analysis

3.2

$<2.800$

$<1.100$

$<2.000$

$<2.500$

$<0.080$

$<0.370$

Feed

Analysis

Calc (a)

Recovery

304

382

397

396

408

830

857

263

267

$97 \%$

$98 \%$

186

158

$96 \% \quad 97 \%$

191

$97 \%$

160

$83 \%$

$97 \%$

$97 \%$

$98 \%$

$99 \%$

(a) Volume of solution after fifth wash was 0.238 liters 
Table 6 Continued

Metal Impurities

\begin{tabular}{|c|c|c|}
\hline$\underset{(\mu \mathrm{g} / \mathrm{ml})}{\mathrm{Al}}$ & $\underset{\mu \mathrm{g} / \mathrm{m}}{\mathrm{Ca}}$ & \\
\hline
\end{tabular}

Simulant

Makeup

1071

66

4955

215

237

673

229

Analysis 1002

65

205

224

682

215

Supernate

Analysis

637

40.5

3465

131

145

428

140

Predict

40.6

3326

128

140

134

1 st Wash

Analysis

329

21.0

1654

65.5

74.2

218

214

72.4

$20.2 \quad 1732$

65.6

72.3

70.1

2nd Wash

Analysis

165

10.6

838

34.5

37.5

110

36.1

Model

159

10.1

866

36.2

107

35.0

3rd Wash

Analysis

81.1

5.7

399

16.9

18.6

53.3

17.5

Model

5.1

433

16.4

18.1

53.5

17.5

4th Wash

Analysis

40.2

3.2

206

7.6

8.2

9.1

9.0

26.1

8.8

Model

39.8

2.5

217

26.8

8.8

5th Wash

Analysis

Model

19.4

$1.7 \quad 100$

4.1

4.6

13.1

13.4

4.4

19.9

1.3

108

4.1

4.5

4.4

Feed

Analysis

13.5

2.6

51.0

2.1

2.4

6.8

2.8

Calc (a)

9.7

0.6

52.8

2.0

2.2

6.5

2.1

(a) Volume of solution after fifth wash was 0.238 liters 
Table 7 Oxalate Solubility Data for Experiment ACP-7

Lanthanides

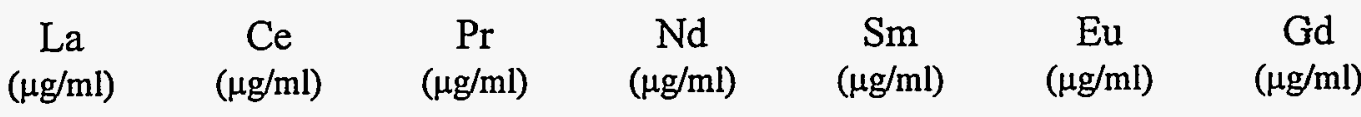

\section{$\underline{\text { Simulant }}$} Makeup

Analysis

700

$$
807
$$

802

797

1700

502

500

321

775

1674

522

374

312

Supernate

Analysis

$$
9.5<2.800
$$$$
<1.100
$$$$
<2.000
$$$$
<2.500
$$

1st Wash

Analysis

$$
5.2<2.800
$$

$<1.100$

$<2.000$

$<2.500$

$0.1<0.370$

2nd Wash

Analysis

3.8

$$
<2.800
$$

$<1.100$

$<2.000$

$<2.500$

0.1

$<0.370$

3rd Wash

Analysis

$3.2<2.800<1.100$

$<2.000$

$<2.500$

0.1

$<0.370$

4th Wash

Analysis

$2.6<2.800$

$$
<1.100
$$

$<2.000$

$<2.500$

$<0.080$

$<0.370$

5th Wash

Analysis

$$
2.4
$$

$<2.800$

$<1.100$

$<2.000$

$<2.500$

0.1

$<0.370$

Feed

Analysis

Calc (a)

Recovery

356
364
$98 \%$

385

421

863

856

277

195

167

$396 \quad 408$

$97 \%$

$103 \%$

$101 \%$

267

191

160

$104 \% \quad 102 \%$

$104 \%$

(a) Volume of solution after fifth wash was 0.239 liters 
Table 7 Continued

Metal Impurities

$\begin{array}{ccccccc}\mathrm{Al} & \mathrm{Ca} & \mathrm{Fe} & \mathrm{K} & \mathrm{Mn} & \underset{(\mu \mathrm{ga}}{\mathrm{Na}} & \underset{(\mu \mathrm{ml})}{\mathrm{Ni}} \\ (\mu \mathrm{g} / \mathrm{ml}) & (\mu \mathrm{g} / \mathrm{ml}) & (\mu \mathrm{g} / \mathrm{ml}) & (\mu \mathrm{g} / \mathrm{ml}) & (\mu \mathrm{g} / \mathrm{ml}) & \underset{(\mu \mathrm{g} / \mathrm{ml})}{ }\end{array}$

\section{$\underline{\text { Simulant }}$}

Makeup

1071

66.0

4955

215

202

237

673

229

65.4

5405

221

675

212

Supernate

Analysis

324

20.9

1648

66.6

76.4

215

74.2

Predict

314

20.6

63.5

69.5

66.7

1st Wash

Analysis

158

10.9

794

32.6

37.1

105

36.1

Model

162

10.5

824

38.2

108

37.1

2nd Wash

Analysis

78.7

5.9

404

15.7

18.5

52.2

18.1

Model

81.0

5.2

412

16.6

19.1

53.8

18.5

3rd Wash

Analysis

40.1

2.8

205

7.5

9.5

26.7

9.3

Model

40.5

2.6

206

8.3

9.5

26.9

9.3

4th Wash

Analysis

19.3

1.9

102

3.8

4.5

12.0

4.4

Model

20.3

1.3

103

4.2

4.8

13.4

4.6

5th Wash

Analysis

9.6

1.2

49.8

2.0

2.3

6.4

2.3

Model

10.1

0.7

51.5

2.1

2.4

6.7

2.3

Feed

Analysis

9.0

3.2

27.3

1.0

1.5

4.2

2.6

Calc (a)

5.0

0.3

1.0

1.2

3.3

1.1

(a) Volume of solution after fifth wash was 0.239 liters 
Table 8 Oxalate Solubility Data for Experiment ACP-8 Lanthanides

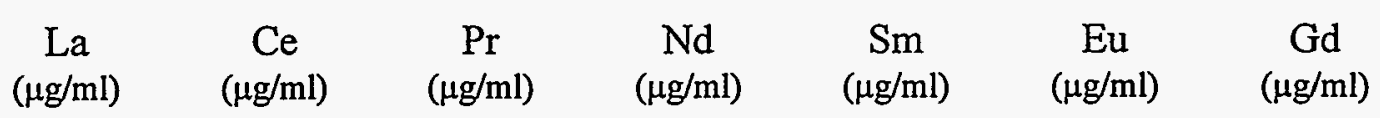

\begin{tabular}{|c|c|c|c|c|c|c|c|}
\hline \multicolumn{8}{|l|}{ Simulant } \\
\hline Makeup & 700 & 807 & 802 & 1700 & 502 & 500 & 321 \\
\hline Analysis & 712 & 775 & 797 & 1674 & 522 & 374 & 312 \\
\hline \multicolumn{8}{|l|}{ Supernate } \\
\hline Analysis & 308 & 219 & 153 & 242 & 48.6 & 29.0 & 27.9 \\
\hline \multicolumn{8}{|l|}{ 1st Wash } \\
\hline Analysis & 57.7 & 20.5 & 8.3 & 8.4 & $<2.500$ & 0.5 & 0.5 \\
\hline \multicolumn{8}{|l|}{ 2nd Wash } \\
\hline Analysis & 20.8 & 4.8 & 1.7 & $<2.000$ & $<2.500$ & $<0.080$ & $<0.370$ \\
\hline \multicolumn{8}{|l|}{ 3rd Wash } \\
\hline Analysis & 10.2 & $<2.800$ & $<1.100$ & $<2.000$ & $<2.500$ & $<0.080$ & $<0.370$ \\
\hline \multicolumn{8}{|l|}{ 4th Wash } \\
\hline Analysis & 6.0 & $<2.800$ & $<1.100$ & $<2.000$ & $<2.500$ & $<0.080$ & $<0.370$ \\
\hline \multicolumn{8}{|l|}{ 5th Wash } \\
\hline Analysis & 3.9 & $<2.800$ & $<1.100$ & $<2.000$ & $<2.500$ & $<0.080$ & $<0.370$ \\
\hline \multicolumn{8}{|l|}{ Eeed } \\
\hline Analysis & 262 & 351 & 378 & 810 & 261 & 188 & 158 \\
\hline Calc (a) & 357 & 389 & 400 & 840 & 262 & 188 & 157 \\
\hline Recovery & $73 \%$ & $90 \%$ & $94 \%$ & $96 \%$ & $100 \%$ & $100 \%$ & $101 \%$ \\
\hline
\end{tabular}

(a) Volume of solution after fifth wash was 0.248 liters 
Table 8 Continued

Metal Impurities

\begin{tabular}{|c|c|c|c|}
\hline$\underset{(\mu \mathrm{g} / \mathrm{ml})}{\mathrm{Al}}$ & $\underset{(\mu \mathrm{g} / \mathrm{m})}{\mathrm{Ca}}$ & $\underset{(\mu \mathrm{g} / \mathrm{n}}{\mathrm{Fe}}$ & $\underset{(\mu \mathrm{g} / \mathrm{h}}{\mathrm{K}}$ \\
\hline
\end{tabular}

\begin{tabular}{cccccccc} 
Simulant & & & & & & \\
Makeup & 1071 & 66.0 & 4955 & 215 & 237 & 673 & 229 \\
Analysis & 999 & 65.4 & 5405 & 202 & 221 & 675 & 212 \\
& & & & & & & \\
Supernate & & & & & & & \\
Analysis & 803 & 52.2 & 4227 & 172 & 185 & 542 & 178 \\
Predict & 783 & 51.3 & 4236 & 158 & 173 & 529 & 166 \\
& & & & & & & \\
1st Wash & & & & & & & \\
Analysis & 401 & 26.1 & 1971 & 86.2 & 92.3 & 267 & 88.7 \\
Model & 402 & 26.1 & 2113 & 86.1 & 92.3 & 271 & 88.9 \\
. & & & & & & & \\
2nd Wash & & & & & & & \\
Analysis & 196 & 13.0 & 992 & 43.5 & 45.5 & 131 & 43.9 \\
Model & 201 & 13.1 & 1057 & 43.1 & 46.1 & 136 & 44.5 \\
& & & & & & & \\
3rd Wash & & & & & & & \\
\hline Analysis & 97.6 & 6.6 & 480 & 19.3 & 22.3 & 64.3 & 21.5 \\
Model & 100 & 6.5 & 528 & 21.5 & 23.1 & 67.8 & 22.2 \\
& & & & & & & \\
4th Wash & & & & & & & \\
\hline Analysis & 47.4 & 3.5 & 240 & 10.0 & 11.0 & 31.3 & 10.7 \\
Model & 50.2 & 3.3 & 264 & 10.8 & 11.5 & 33.9 & 11.1 \\
& & & & & & & \\
5th Wash & & & & & & & \\
\hline Analysis & 23.1 & 1.9 & 115 & 4.7 & 5.3 & 15.6 & 5.2 \\
Model & 25.1 & 1.6 & 132 & 5.4 & 5.8 & 16.9 & 5.6 \\
Feed & & & & & & & \\
Analysis & 9.9 & 1.9 & 56.3 & 2.4 & 2.7 & 8.4 & 3.0 \\
Calc & 12.5 & 0.8 & 65.8 & 2.7 & 2.9 & 8.4 & 2.8
\end{tabular}

(a) Volume of solution after fifth wash was 0.248 liters 
Table 9 Oxalate Solubility Data for Experiment ACP-9

Lanthanides

$\underset{(\mu \mathrm{g} / \mathrm{ml})}{\mathrm{La}} \quad \underset{(\mu \mathrm{g} / \mathrm{ml})}{\mathrm{Ce}} \quad \underset{(\mu \mathrm{g} / \mathrm{ml})}{\mathrm{Pr}} \quad \underset{(\mu \mathrm{g} / \mathrm{ml})}{\mathrm{Nd}} \quad \underset{(\mu \mathrm{g} / \mathrm{ml})}{\mathrm{Sm}} \quad \underset{(\mu \mathrm{g} / \mathrm{ml})}{\mathrm{Eu}} \quad \underset{(\mu \mathrm{g} / \mathrm{ml})}{\mathrm{Gd}}$

$\begin{array}{lccccccc}\text { Simulant } & & & & & & & \\ \text { Makeup } & 700 & 807 & 802 & 1700 & 502 & 500 & 321 \\ \text { Analysis } & 712 & 775 & 797 & 1674 & 522 & 374 & 312 \\ \text { Supernate } & & & & & & & \\ \text { Analysis } & 77.4 & 29.1 & 12.3 & 14.0 & <2.500 & 1.0 & 0.9\end{array}$

Metal Impurities

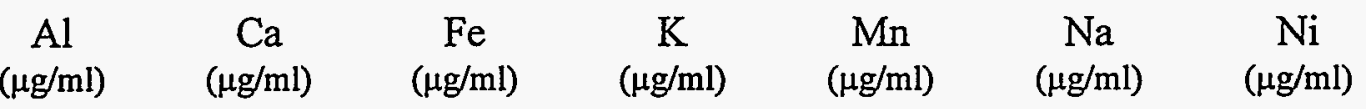

$\begin{array}{cccccccc}\text { Simulant } & & & & & & \\ \text { Makeup } & 1071 & 66.0 & 4955 & 215 & 237 & 673 & 229 \\ \text { Analysis } & 999 & 65.4 & 5405 & 202 & 221 & 675 & 212 \\ & & & & & & & \\ \text { Supernate } & & & & & & & \\ \text { Analysis } & 640 & 40.9 & 3234 & 127 & 146 & 433 & 138 \\ \text { Predict } & 624 & 40.9 & 3378 & 126 & 138 & 422 & 133\end{array}$


Table 10 Oxalate Solubility Data for Experiment ACP-10

Lanthanides

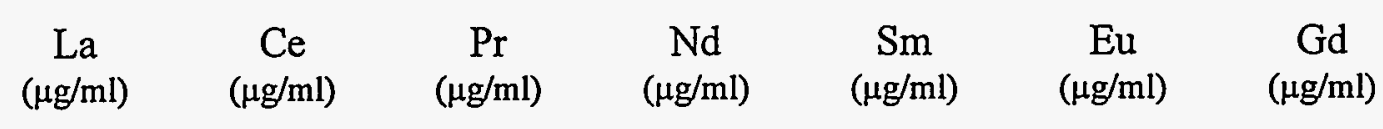

\begin{tabular}{|c|c|c|c|c|c|c|c|}
\hline \multicolumn{8}{|l|}{ Simulant } \\
\hline Makeup & 700 & 807 & 802 & 1700 & 502 & 500 & 321 \\
\hline Analysis & 712 & 775 & 797 & 1674 & 522 & 374 & 312 \\
\hline \multicolumn{8}{|l|}{ Supernate } \\
\hline Analysis & 77.2 & 30.2 & 13.5 & 15.6 & $<2.500$ & 1.3 & 1.3 \\
\hline \multicolumn{8}{|l|}{1 st Wash } \\
\hline Analysis & 26.9 & 6.3 & 1.7 & $<2.000$ & $<2.500$ & 0.1 & $<0.370$ \\
\hline \multicolumn{8}{|l|}{ 2nd Wash } \\
\hline Analysis & 12.4 & $<2.800$ & $<1.100$ & $<2.000$ & $<2.500$ & $<0.080$ & $<0.370$ \\
\hline \multicolumn{8}{|l|}{ 3rd Wash } \\
\hline Analysis & 6.6 & $<2.800$ & $<1.100$ & $<2.000$ & $<2.500$ & $<0.080$ & $<0.370$ \\
\hline \multicolumn{8}{|l|}{ 4th Wash } \\
\hline Analysis & 3.9 & $<2.800$ & $<1.100$ & $<2.000$ & $<2.500$ & $<0.080$ & $<0.370$ \\
\hline \multicolumn{8}{|l|}{ 5th Wash } \\
\hline Analysis & 2.6 & $<2.800$ & $<1.100$ & $<2.000$ & $<2.500$ & $<0.080$ & $<0.370$ \\
\hline \multicolumn{8}{|l|}{ Feed } \\
\hline Analysis & 310 & 385 & 403 & 854 & 268 & 190 & 162 \\
\hline Calc (a) & 360 & 392 & 403 & 847 & 264 & 189 & 158 \\
\hline Recovery & $86 \%$ & $98 \%$ & $100 \%$ & $101 \%$ & $101 \%$ & $100 \%$ & $102 \%$ \\
\hline
\end{tabular}

(a) Volume of solution after fifth wash was 0.244 liters 
Table 10 Continued

Metal Impurities

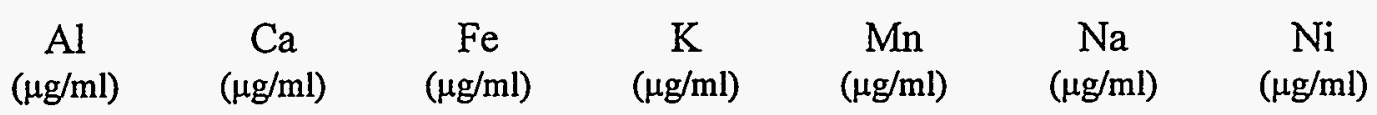

\begin{tabular}{|c|c|c|c|c|c|c|c|}
\hline \multicolumn{8}{|l|}{ Simulant } \\
\hline Makeup & 1071 & 66.0 & 4955 & 215 & 237 & 673 & 229 \\
\hline Analysis & 999 & 65.4 & 5405 & 202 & 221 & 675 & 212 \\
\hline \multicolumn{8}{|l|}{ Supernate } \\
\hline Analysis & 639 & 51.3 & 3260 & 130 & 146 & 432 & 141 \\
\hline Predict & 624 & 40.9 & 3378 & 126 & 138 & 422 & 133 \\
\hline \multicolumn{8}{|l|}{ 1st Wash } \\
\hline Analysis & 312 & 22.4 & 1518 & 49.1 & 71.3 & 209 & 68.1 \\
\hline Model & 319 & 25.7 & 1630 & 64.8 & 73.2 & 216 & 70.3 \\
\hline \multicolumn{8}{|l|}{ 2nd Wash } \\
\hline Analysis & 159 & 10.7 & 778 & 32.5 & 36.4 & 105 & 34.9 \\
\hline Model & 160 & 12.8 & 815 & 32.4 & 36.6 & 108 & 35.1 \\
\hline \multicolumn{8}{|l|}{ 3rd Wash } \\
\hline Analysis & 80.4 & 8.7 & 390 & 15.4 & 18.3 & 52.8 & 17.4 \\
\hline Model & 79.8 & 6.4 & 407 & 16.2 & 18.3 & 53.9 & 17.6 \\
\hline \multicolumn{8}{|l|}{ 4th Wash } \\
\hline Analysis & 38.3 & 3.2 & 190 & 7.3 & 8.6 & 25.5 & 8.0 \\
\hline Model & 39.9 & 3.2 & 204 & 8.1 & 9.2 & 27.0 & 8.8 \\
\hline \multicolumn{8}{|l|}{ 5th Wash } \\
\hline Analysis & 19.4 & 1.7 & 94 & 3.9 & 4.4 & 12.5 & 4.0 \\
\hline Model & 20.0 & 1.6 & 102 & 4.0 & 4.6 & 13.5 & 4.4 \\
\hline \multicolumn{8}{|l|}{ Feed } \\
\hline Analysis & 16.0 & (a) & 50.6 & 1.9 & 2.6 & 8.0 & 2.9 \\
\hline Calc (b) & 9.9 & 0.8 & 50.3 & 2.0 & 2.3 & 6.7 & 2.2 \\
\hline
\end{tabular}

(a) Not Available

(b) Volume of solution after fifth wash was 0.244 liters 
Table 11 Selected Stability Constants for Oxalic Acid ${ }^{6}$

\begin{tabular}{|c|c|c|c|c|}
\hline Metal Ion & Equilibrium & $\begin{array}{c}\log \mathrm{K} \\
25^{\circ} \mathrm{C}, 0.1^{\mathrm{a}}\end{array}$ & $\begin{array}{c}\log \mathrm{K} \\
25^{\circ} \mathrm{C}, 1.0^{\mathrm{a}}\end{array}$ & $\begin{array}{c}\log \mathrm{K} \\
25^{\circ} \mathrm{C}, 0^{\mathrm{a}}\end{array}$ \\
\hline $\mathrm{Al}^{3+}$ & $\begin{array}{c}\mathrm{ML} / \mathrm{M} \cdot \mathrm{L} \\
\mathrm{ML}_{2} / \mathrm{M} \cdot \mathrm{L}^{2} \\
\mathrm{ML}_{3} / \mathrm{M} \cdot \mathrm{L}^{3}\end{array}$ & & $\begin{array}{c}6.1 \\
11.09 \\
15.12\end{array}$ & \\
\hline $\mathrm{Ca}^{2+}$ & $\begin{array}{c}\mathrm{ML} / \mathrm{M} \cdot \mathrm{L} \\
\mathrm{ML}_{2} / \mathrm{M} \cdot \mathrm{L}^{2}\end{array}$ & & $\begin{array}{l}1.66 \\
2.69\end{array}$ & $3.00^{\mathrm{b}}$ \\
\hline $\mathrm{Fe}^{3+}$ & $\begin{array}{c}\mathrm{ML} / \mathrm{M} \bullet \mathrm{L} \\
\mathrm{ML}_{2} / \mathrm{M} \cdot \mathrm{L}^{2} \\
\mathrm{ML}_{3} / \mathrm{M} \bullet \mathrm{L}^{3} \\
\mathrm{MHL} / \mathrm{M} \bullet \mathrm{HL}\end{array}$ & $\begin{array}{c}7.53^{\mathrm{c}} \pm 0.1 \\
13.64^{\mathrm{c}} \\
18.49^{\mathrm{c}} \\
4.35^{\mathrm{c}}\end{array}$ & 7.59 & $7.74^{\mathrm{d}}$ \\
\hline $\mathrm{K}^{+}$ & $M L / M \cdot L$ & & & $-0.8^{\mathrm{b}}$ \\
\hline $\mathrm{Mn}^{2+}$ & $\begin{array}{c}\mathrm{ML} / \mathrm{M} \cdot \mathrm{L} \\
\mathrm{ML}_{2} / \mathrm{M} \cdot \mathrm{L}^{2}\end{array}$ & $\begin{array}{l}3.2 \\
4.4\end{array}$ & & $3.95 \pm 0.03$ \\
\hline $\mathrm{Ni}^{2+}$ & $\mathrm{ML} / \mathrm{M} \bullet \mathrm{L}$ & & & 5.16 \\
\hline $\mathrm{UO}_{2}{ }^{2+}$ & $\begin{array}{c}\mathrm{ML} / \mathrm{M} \cdot \mathrm{L} \\
\mathrm{ML}_{2} / \mathrm{M} \cdot \mathrm{L}^{2} \\
\mathrm{ML}_{3} / \mathrm{M} \cdot \mathrm{L}^{3}\end{array}$ & $\begin{array}{c}6.36^{\mathrm{e}} \\
10.59^{\mathrm{e}}\end{array}$ & $\begin{array}{c}5.99^{\mathrm{e}} \\
10.64^{\mathrm{e}} \\
11.0^{\mathrm{e}}\end{array}$ & \\
\hline $\mathrm{Mn}^{3+}$ & $\begin{array}{c}\mathrm{ML} / \mathrm{M} \cdot \mathrm{L} \\
\mathrm{ML}_{2} / \mathrm{M} \cdot \mathrm{L}^{2} \\
\mathrm{ML}_{3} / \mathrm{M} \cdot \mathrm{L}^{3}\end{array}$ & & $\begin{array}{c}9.98^{f} \\
16.57^{f} \\
18.42^{f}\end{array}$ & \\
\hline
\end{tabular}
(a) Ionic Strength
(b) $18^{\circ} \mathrm{C}$
(c) Ionic Strength equal to 0.5
(d) Ionic Strength equal to 3.0
(e) $20^{\circ} \mathrm{C}$
(f) Ionic Strength equal to 2.0 
Table 12 Solution Analysis for Precipitate Slurry Scouting Experiments

Lanthanides

Exp't

\begin{tabular}{|c|c|c|c|}
\hline $\begin{array}{c}\mathrm{Ce} \\
(\mu \mathrm{g} / \mathrm{ml})\end{array}$ & $\underset{(\mu \mathrm{g} / \mathrm{ml})}{\operatorname{Pr}}$ & $\underset{(\mu \mathrm{g} / \mathrm{ml})}{\mathrm{Nd}}$ & $\underset{(\mu \mathrm{g} / \mathrm{ml})}{\mathrm{Sm}}$ \\
\hline
\end{tabular}

ACP-11 $\underline{\text { Simulant }}$

$\begin{array}{llllllll}\text { Makeup } & 4026 & 4760 & 4600 & 9835 & 2881 & 2912 & 1815\end{array}$

$\begin{array}{llllllll}\text { Analysis } & 4157 & 4757 & 4605 & 9762 & 2996 & 2206 & 1792\end{array}$

Supernate

$\begin{array}{llllllll}\text { Analysis } & 1207 & 956 & 689 & 1170 & 254 & 159 & 138\end{array}$

ACP-12 Simulant

$\begin{array}{llllllll}\text { Makeup } & 6125 & 6912 & 6903 & 14656 & 4437 & 4374 & 2756\end{array}$

$\begin{array}{llllllll}\text { Analysis } & 6199 & 6893 & 6750 & 14217 & 4512 & 3235 & 2649\end{array}$

$\underline{\text { Supernate }}$

$\begin{array}{llllllll}\text { Analysis } & 2219 & 1911 & 1602 & 2853 & 726 & 452 & 388\end{array}$

ACP-13 Simulant

$\begin{array}{llllllll}\text { Makeup } & 6054 & 6989 & 6924 & 14670 & 4365 & 4050 & 2736\end{array}$

$\begin{array}{llllllll}\text { Analysis } & 6406 & 7130 & 7159 & 14735 & 4719 & 3120 & 2753\end{array}$

Supernate

Analysis

83.6

9.0

3.4

$4.2<2.500$

0.8

0.6 
Table 12 Continued

Metal Impurities

$\operatorname{Exp}^{\prime} t$

$\begin{array}{lllllll}\mathrm{Al} & \mathrm{Ca} & \mathrm{Fe} & \mathrm{K} & \mathrm{Mn} & \mathrm{Na} & \mathrm{Ni}\end{array}$

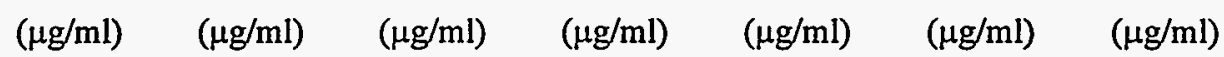

ACP-11 Simulant

$\begin{array}{llllllll}\text { Makeup } & 6173 & 377 & 28580 & 1253 & 1352 & 3871 & 1303\end{array}$

$\begin{array}{llllllll}\text { Analysis } & 5930 & 379 & 30409 & 1186 & 1330 & 3961 & 1256\end{array}$

Supernate

$\begin{array}{llllllll}\text { Analysis } & 2877 & 223 & 13976 & 575 & 660 & 1904 & 629\end{array}$

ACP-12 Simulant

$\begin{array}{llllllll}\text { Makeup } & 9315 & 570 & 42786 & 2047 & 2048 & 5801 & 1975\end{array}$

$\begin{array}{llllllll}\text { Analysis } & 8804 & 581 & 44204 & 1923 & 1980 & 5894 & 1868\end{array}$

Supernate

$\begin{array}{llllllll}\text { Analysis } & 4056 & 428 & 20754 & 872 & 928 & 2736 & 913\end{array}$

ACP-13 Simulant

$\begin{array}{llllllll}\text { Makeup } & 1068 & 66 & 4955 & 213 & 241 & 671 & 230\end{array}$

$\begin{array}{llllllll}\text { Analysis } & 991 & \text { (a) } & 5386 & 207 & 236 & 711 & 231\end{array}$

Supernate

$\begin{array}{llllllll}\text { Analysis } & 460 & 56.6 & 2345 & 94.3 & 109 & 315 & 104\end{array}$

(a) Analytical results were not available. 
Revision 0

Table 13 Specific Volume of Oxalate Slurry

\begin{tabular}{|c|c|c|c|c|}
\hline Experiment & $\begin{array}{l}\text { Simulant } \\
\text { Volume } \\
\text { (liters) }\end{array}$ & $\begin{array}{l}\text { Lanthanide (a) } \\
\text { (moles) }\end{array}$ & $\begin{array}{c}\text { Slurry Volume } \\
\text { (liters) }\end{array}$ & $\begin{array}{c}\text { Specific Volume } \\
\text { (liters/mole) }\end{array}$ \\
\hline ACP-11 & 0.209 & 0.044 & 0.02 & 0.5 \\
\hline ACP-12 & 0.212 & 0.065 & 0.03 & 0.5 \\
\hline ACP-13 & 0.212 & 0.068 & 0.05 & 0.7 \\
\hline ACP-14 & 1.960 & 0.656 & 0.3 & 0.5 \\
\hline
\end{tabular}

(a) The moles of lanthanides are based on simulant concentrations given in Tables A.6-A.8. 
Table 14 Oxalate Solubility Data for Experiment ACP-14

$$
\text { Lanthanides }^{(\text {a) }}
$$

$\underset{(\mu \mathrm{g} / \mathrm{ml})}{\mathrm{La}} \underset{(\mu \mathrm{g} / \mathrm{ml})}{\mathrm{Ce}} \quad \underset{(\mu \mathrm{g} / \mathrm{ml})}{\mathrm{Pr}} \quad \underset{(\mu \mathrm{g} / \mathrm{ml})}{\mathrm{Nd}} \quad \underset{(\mu \mathrm{g} / \mathrm{ml})}{\mathrm{Sm}} \quad \underset{(\mu \mathrm{g} / \mathrm{ml})}{\mathrm{Eu}} \quad \underset{(\mu \mathrm{g} / \mathrm{ml})}{\mathrm{Gd}}$

$\begin{array}{llllllll}\text { Simulant } & & & & & & & \\ \text { Makeup } & 6055 & 6909 & 6910 & 14686 & 4338 & 4318 & 2733 \\ \text { Analysis } & 6536 & 7248 & 7342 & 15146 & 4859 & 4377 & 2791 \\ \text { Supernate } & & & & & & & \\ \text { Analysis } & 86.4 & 7.8 & 2.0 & 2.7 & <2.500 & 0.69 & <0.370\end{array}$

Metal Impurities ${ }^{(a)}$

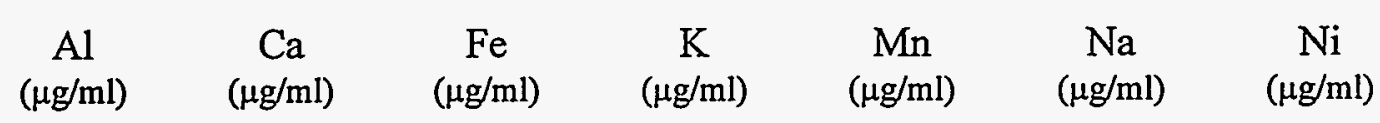

$\begin{array}{cccccccc}\text { Simulant } & & & & & & & \\ \text { Makeup } & 1070 & 66 & 4950 & 216 & 237 & 671 & 228 \\ \text { Analysis } & 1034 & \text { (b) } & 5117 & 198 & 239 & 715 & 232 \\ & & & & & & & \\ \text { Supernate } & & & & & & & \\ \text { Analysis } & 440 & 30.4 & 2253 & 90.8 & 102 & 300 & 98.2 \\ \text { Predict } & 465 & 28.6 & 2151 & 94.0 & 103 & 292 & 98.9\end{array}$

(a) Supernate temperature was $35^{\circ} \mathrm{C}$ during sampling.

(b) Analytical results were not available. 


\section{Appendix A - Preparation of Simulated Solutions}

\section{Uranium Solubility Experiments}

A 0.6 gram/liter $(600 \mu \mathrm{g} / \mathrm{ml})$ uranium solution was prepared by dissolving 1.3094 grams of depleted uranyl nitrate hexahydrate (UNH) in 1 liter of $1.0 \mathrm{M}$ nitric acid. The UNH was obtained from Mallinckrodt and assayed $100.6 \%$. The concentrated nitric acid used to prepare the $1.0 \mathrm{M}$ solution was obtained from E. M. Science and assayed $69-71 \%$ (15.7M). The prepared and analyzed concentrations for the solution are given in Table A.1. This solution was used for experiments ACP-1 and ACP-2.

Table A.1 Simulated Uranium Solution

$\begin{array}{ccccc}\text { Element } & \text { Starting Material } & \text { Compound Mass } & \begin{array}{c}\text { Element } \\ \text { Concentration } \\ (\mu \mathrm{g} / \mathrm{ml})\end{array} & \begin{array}{c}\text { Analyzed } \\ \text { Concentration (a) } \\ (\mu \mathrm{g} / \mathrm{ml})\end{array} \\ \text { Uranium } & \mathrm{UO}_{2}\left(\mathrm{NO}_{3}\right) \cdot 6 \mathrm{H}_{2} \mathrm{O} & 1.3094 & 621 & 567 \pm 20\end{array}$

(a) The analyzed concentration is given at the $95 \%$ confidence limit.

A $0.6 \mathrm{gram} / \mathrm{liter}(600 \mu \mathrm{g} / \mathrm{ml})$ uranium $/ 5 \mathrm{gram} /$ liter $(5000 \mu \mathrm{g} / \mathrm{ml})$ lanthanum solution was prepared by initially dissolving 6.0050 grams of lanthanum oxide $\left(\mathrm{La}_{2} \mathrm{O}_{3}\right)$ in $50 \mathrm{ml}$ of $3.2 \mathrm{M}$ nitric acid. The volume and concentration were calculated to give a $1.0 \mathrm{M}$ nitric acid solution upon dissolution. Once the dissolution was complete, the solution was diluted to a 1 liter volume with 1.0M nitric acid. Lanthanum nitrate hexahydrate $\left(\mathrm{La}\left(\mathrm{NO}_{3}\right)_{3} \bullet 6 \mathrm{H}_{2} \mathrm{O}\right)$, calcined to a constant mass at $900^{\circ} \mathrm{C}$, was used as the starting material to prepare the $\mathrm{La}_{2} \mathrm{O}_{3}$. The $\mathrm{La}\left(\mathrm{NO}_{3}\right)_{3} \bullet 6 \mathrm{H}_{2} \mathrm{O}$ was obtained from Fisher Scientific (Lot No. 915064). Once the 5 gram/liter lanthanum solution was prepared, 1.3047 grams of UNH were dissolved directly in the lanthanum solution. The UNH was obtained from Mallinckrodt and assayed $100.6 \%$. The concentrated nitric acid used to prepare the 3.2 and $1.0 \mathrm{M}$ solutions was obtained from E. M. Science and assayed $69-71 \%$ (15.7M). The prepared and analyzed concentrations for the solution are given in Table A.2. This solution was used for experiments ACP-3, ACP-4, and ACP-5.

Table A.2 Simulated Uranium/Lanthanum Solution

$\begin{array}{ccccc}\text { Element } & \text { Starting Material } & \text { Compound Mass } & \begin{array}{c}\text { Element } \\ \text { Concentration } \\ (\mu \mathrm{g} / \mathrm{ml})\end{array} & \begin{array}{c}\text { Analyzed } \\ \text { Concentration (a) } \\ (\mu \mathrm{g} / \mathrm{ml})\end{array} \\ \begin{array}{c}\text { Uranium } \\ \text { Lanthanum }\end{array} & \mathrm{UO}_{2}\left(\mathrm{NO}_{3}\right) \bullet 6 \mathrm{H}_{2} \mathrm{O} & 1.3047 & 621 & 563 \pm 18 \\ \mathrm{La}_{2} \mathrm{O}_{3} & 6.0050 & 5120 & .5117 \pm 75\end{array}$

(a) The analyzed concentrations are given at the $95 \%$ confidence limit. 


\section{Simulated Am/Cm Pretreatment Experiments}

The simulated Tank 17.1 solution was prepared by dissolving the starting materials listed in Table A. 3 in 2 liters of $1.0 \mathrm{M}$ nitric acid. This procedure simulates the tank contents following formic acid denitration. The exception to this practice was the dissolution of 1.4583 grams of manganese sulfate monohydrate $\left(\mathrm{MnSO}_{4} \bullet \mathrm{H}_{2} \mathrm{O}\right)$ in $8 \mathrm{ml}$ of $3.2 \mathrm{M}$ nitric acid. The volume and concentration were calculated to give a $1.0 \mathrm{M}$ nitric acid solution upon dissolution. The concentrated nitric acid used to prepare the 3.2 and $1.0 \mathrm{M}$ solutions was obtained from E. M. Science and Fisher Scientific and assayed 69-71 and 69.6\% (15.7M), respectively.

Table A.3 Starting Materials for Simulated Tank 17.1 Solution

\begin{tabular}{|c|c|c|c|c|}
\hline Element & Starting Material & Manufacturer & Lot No. & Assay \\
\hline Lanthanum & $\mathrm{La}\left(\mathrm{NO}_{3}\right)_{3} \bullet 6 \mathrm{H}_{2} \mathrm{O}$ & Fisher Scientific & 947511 & $\begin{array}{c}\text { Laboratory } \\
\text { Grade }\end{array}$ \\
\hline Cerium & $\mathrm{Ce}\left(\mathrm{NO}_{3}\right)_{3} \bullet 6 \mathrm{H}_{2} \mathrm{O}$ & $\begin{array}{l}\text { Aldrich } \\
\text { Chemical } \\
\text { Company }\end{array}$ & 01108PY & $99 \%(1-2 \% \mathrm{La})$ \\
\hline Praseodymium & $\operatorname{Pr}\left(\mathrm{NO}_{3}\right)_{3} \bullet 6 \mathrm{H}_{2} \mathrm{O}$ & $\begin{array}{l}\text { Aldrich } \\
\text { Chemical } \\
\text { Company }\end{array}$ & $12513 \mathrm{AN}$ & $99.9 \%$ \\
\hline Neodymium & $\mathrm{Nd}\left(\mathrm{NO}_{3}\right)_{3} \bullet 6 \mathrm{H}_{2} \mathrm{O}$ & $\begin{array}{l}\text { Aldrich } \\
\text { Chemical } \\
\text { Company }\end{array}$ & $18618 \mathrm{MF}$ & $99.9 \%$ \\
\hline Samarium & $\mathrm{Sm}\left(\mathrm{NO}_{3}\right)_{3} \bullet 6 \mathrm{H}_{2} \mathrm{O}$ & Johnson Matthey & $\mathrm{B} 16 \mathrm{~F} 16$ & $99.9 \%$ \\
\hline Europium & $\mathrm{Eu}\left(\mathrm{NO}_{3}\right)_{3}$ & Johnson Matthey & $\mathrm{P} 1148$ & $99.9 \%$ \\
\hline Gadolinium & $\mathrm{Gd}\left(\mathrm{NO}_{3}\right)_{3} \bullet 6 \mathrm{H}_{2} \mathrm{O}$ & $\begin{array}{l}\text { Aldrich } \\
\text { Chemical } \\
\text { Company }\end{array}$ & 00630PF & $99.9 \%$ \\
\hline Aluminum & $\mathrm{Al}\left(\mathrm{NO}_{3}\right)_{3} \bullet 9 \mathrm{H}_{2} \mathrm{O}$ & Fisher Scientific & $942038 \mathrm{C}$ & $98.80 \%$ \\
\hline Calcium & $\mathrm{Ca}\left(\mathrm{NO}_{3}\right)_{2} \bullet 4 \mathrm{H}_{2} \mathrm{O}$ & E. M. Science & 33141329 & $99.00 \%$ \\
\hline Iron & $\mathrm{Fe}\left(\mathrm{NO}_{3}\right)_{3} \bullet 9 \mathrm{H}_{2} \mathrm{O}$ & J. T. Baker & C13332 & $99.6 \%$ \\
\hline Potassium & $\mathrm{KNO}_{3}$ & Mallinckrodt & 45059 & $>99 \%$ \\
\hline Manganese & $\mathrm{MnSO}_{4} \bullet \mathrm{H}_{2} \mathrm{O}$ & E. M. Science & 34187506 & $99.0-101.0 \%$ \\
\hline Sodium & $\mathrm{NaNO}_{3}$ & Fisher Scientific & $941644 \mathrm{~B}$ & $100.10 \%$ \\
\hline Nickel & $\mathrm{Ni}\left(\mathrm{NO}_{3}\right)_{2} \bullet 6 \mathrm{H}_{2} \mathrm{O}$ & J. T. Baker & 45059 & $99.60 \%$ \\
\hline
\end{tabular}

The prepared and analyzed concentrations for the simulated solution are given in Table A.4. This solution was used for experiments ACP-6, ACP-7, ACP-8, ACP-9, and ACP-10. 
Table A.4 Element Concentrations in Simulated Tank 17.1 Solution

$\begin{array}{cccc}\text { Element } & \text { Compound Mass } & \begin{array}{c}\text { Element } \\ \text { Concentration } \\ (\mu \mathrm{g} / \mathrm{ml})\end{array} & \begin{array}{c}\text { Analyzed } \\ \text { Concentration (a) } \\ (\mu \mathrm{g} / \mathrm{ml})\end{array} \\ \text { Lanthanum } & \text { (grams) } & 700 & 712 \pm 6 \\ \text { Cerium } & 4.3667 & 807 & 775 \pm 14 \\ \text { Praseodymium } & 4.9993 & 802 & 797 \pm 6 \\ \text { Neodymium } & 4.9513 & 1700 & 1674 \pm 12 \\ \text { Samarium } & 10.3331 & 502 & 522 \pm 5 \\ \text { Europium } & 2.9700 & 500 & 374 \pm 3 \\ \text { Gadolinium } & 2.2237 & 321 & 312 \pm 2 \\ \text { Aluminum } & 1.8452 & 1071 & 1002 \pm 11 \\ \text { Calcium } & 29.7931 & 66 & 65 \pm 1 \\ \text { Iron } & 0.7778 & 4955 & 5322 \pm 87 \\ \text { Potassium } & 71.6829 & 215 & 205 \pm 2 \\ \text { Manganese } & 1.1123 & 237 & 224 \pm 3 \\ \text { Sodium } & 1.4583 & 673 & 682 \pm 6 \\ \text { Nickel } & 4.9724 & 229 & 215 \pm 3\end{array}$

(a) The analyzed concentrations are given at the $95 \%$ confidence limit.

\section{Slurry Properties of Oxalate Precipitate}

Simulated solutions used to measure the slurry properties of the oxalate precipitate were prepared by dissolving the nitrate (and sulfate) salts of the lanthanide and metal impurities in a measured volume of $1.0 \mathrm{M}$ nitric acid. The concentrated nitric acid used to prepare the solutions was obtained from Fisher Scientific and assayed 69.6\% (15.7M). The starting materials used to prepare the simulated solutions for experiments ACP-11, ACP-12 and ACP-13 were the same as listed in Table A.3. The materials used for experiment ACP-14 were also the same except for those listed in Table A.5.

Table A.5 Starting Materials for Simulated Tank 17.1 Solution for Experiment ACP-14

$\begin{array}{ccccc}\text { Element } & \text { Starting Material } & \text { Manufacturer } & \text { Lot No. } & \text { Assay } \\ \text { Europium } & \mathrm{Eu}\left(\mathrm{NO}_{3}\right)_{3} \bullet 5 \mathrm{H}_{2} \mathrm{O} & \begin{array}{c}\text { Aldrich } \\ \text { Chemical }\end{array} & \text { 01323LF } & 99.9 \% \\ \text { Iron } & \mathrm{Fe}\left(\mathrm{NO}_{3}\right)_{3} \bullet 9 \mathrm{H}_{2} \mathrm{O} & \begin{array}{c}\text { Company } \\ \text { Mallinckrodt }\end{array} & \text { 5032KPPR } & 98.2 \%\end{array}$


The prepared and analyzed concentrations for experiments ACP-11, ACP-12, ACP-13, and ACP-14 are given in Tables A.6 - A.9, respectively.

Table A.6 Element Concentrations in Simulated Tank 17.1 Solution for Experiment ACP-11 Volume 0.250 liters

$\begin{array}{cccc}\text { Element } & \text { Compound Mass } & \begin{array}{c}\text { Element } \\ \text { Concentration } \\ (\mu \mathrm{g} / \mathrm{ml})\end{array} & \begin{array}{c}\text { Analyzed } \\ \text { Concentration (a) } \\ (\mu \mathrm{g} / \mathrm{ml})\end{array} \\ \text { Lanthanum } & (\mathrm{grams}) & 4026 & 4157 \pm 72 \\ \text { Cerium } & 3.1372 & 4760 & 4757 \pm 134 \\ \text { Praseodymium } & 3.6879 & 4600 & 4605 \pm 50 \\ \text { Neodymium } & 3.5500 & 9835 & 9762 \pm 92 \\ \text { Samarium } & 7.4723 & 2881 & 2996 \pm 31 \\ \text { Europium } & 2.1294 & 2912 & 2206 \pm 19 \\ \text { Gadolinium } & 1.6194 & 1815 & 1792 \pm 20 \\ \text { Aluminum } & 1.3023 & 6173 & 5930 \pm 121 \\ \text { Calcium } & 21.4553 & 377 & 379 \pm 12 \\ \text { Iron } & 0.5559 & 28580 & 30409 \pm 382 \\ \text { Potassium } & 51.6865 & 1253 & 1186 \pm 15 \\ \text { Manganese } & 0.8102 & 1352 & 1330 \pm 38 \\ \text { Sodium } & 1.0400 & 3871 & 3961 \pm 50 \\ \text { Nickel } & 3.5779 & 1303 & 1256 \pm 28\end{array}$

(a) The analyzed concentrations are given at the $95 \%$ confidence limit. 
Table A.7 Element Concentrations in Simulated Tank 17.1 Solution for Experiment ACP-12 Volume 0.250 liters

$\begin{array}{cccc}\text { Element } & \text { Compound Mass } & \begin{array}{c}\text { Element } \\ \text { Concentration } \\ (\mu \mathrm{g} / \mathrm{ml})\end{array} & \begin{array}{c}\text { Analyzed } \\ \text { Concentration (a) } \\ (\mu \mathrm{g} / \mathrm{ml})\end{array} \\ \text { Lanthanum } & \text { (grams) } & 6125 & 6199 \pm 59 \\ \text { Cerium } & 4.7733 & 6912 & 6893 \pm 67 \\ \text { Praseodymium } & 5.3552 & 6903 & 6750 \pm 81 \\ \text { Neodymium } & 5.3275 & 14656 & 14217 \pm 146 \\ \text { Samarium } & 11.1350 & 4437 & 4512 \pm 50 \\ \text { Europium } & 3.2792 & 4374 & 3235 \pm 35 \\ \text { Gadolinium } & 2.4322 & 2756 & 2649 \pm 31 \\ \text { Aluminum } & 1.9780 & 9315 & 8804 \pm 152 \\ \text { Calcium } & 32.3767 & 570 & 581 \pm 29 \\ \text { Iron } & 0.8394 & 42786 & 44204 \pm 1615 \\ \text { Potassium } & 77.3794 & 2047 & 1923 \pm 83 \\ \text { Manganese } & 1.3233 & 2048 & 1980 \pm 27 \\ \text { Sodium } & 1.5748 & 5801 & 5894 \pm 64 \\ \text { Nickel } & 5.3613 & 1975 & 1868 \pm 8\end{array}$

(a) The analyzed concentrations are given at the $95 \%$ confidence limit. 
WSRC-TR-96-0074

Revision 0

Table A.8 Element Concentrations in Simulated Tank 17.1 Solution for Experiment ACP-13 Volume 0.250 liters

$\begin{array}{cccc}\text { Element } & \text { Compound Mass } & \begin{array}{c}\text { Element } \\ \text { Concentration } \\ (\mu \mathrm{g} / \mathrm{ml})\end{array} & \begin{array}{c}\text { Analyzed } \\ \text { Concentration (a) } \\ (\mu \mathrm{g} / \mathrm{ml})\end{array} \\ \text { Lanthanum } & \text { (grams) } & 6054 & 6406 \pm 99 \\ \text { Cerium } & 4.7182 & 6989 & 7130 \pm 125 \\ \text { Praseodymium } & 5.4147 & 6924 & 7159 \pm 121 \\ \text { Neodymium } & 5.3441 & 14670 & 14735 \pm 220 \\ \text { Samarium } & 11.1457 & 4365 & 4719 \pm 85 \\ \text { Europium } & 3.2261 & 4050 & 3120 \pm 49 \\ \text { Gadolinium } & 2.2517 & 2736 & 2753 \pm 45 \\ \text { Aluminum } & 1.9630 & 1068 & 991 \pm 28 \\ \text { Calcium } & 3.7115 & 66 & (\mathrm{~b}) \\ \text { Iron } & 0.0965 & 4955 & 5386 \pm 257 \\ \text { Potassium } & 8.9603 & 213 & 207 \pm 18 \\ \text { Manganese } & 0.1377 & 241 & 236 \pm 5 \\ \text { Sodium } & 0.1857 & 671 & 711 \pm 12 \\ \text { Nickel } & 0.6198 & 230 & 231 \pm 4\end{array}$

(a) The analyzed concentrations are given at the $95 \%$ confidence limit.

(b) Analytical results were not available. 
Table A.9 Element Concentrations in Simulated Tank 17.1 Solution for Experiment ACP-14 Volume 2.000 liters

$\begin{array}{cccc}\text { Element } & \text { Compound Mass } & \begin{array}{c}\text { Element } \\ \text { Concentration } \\ (\mu \mathrm{g} / \mathrm{ml})\end{array} & \begin{array}{c}\text { Analyzed } \\ \text { Concentration (a) } \\ (\mu \mathrm{g} / \mathrm{ml})\end{array} \\ \text { Lanthanum } & \text { (grams) } & 6055 & 6536 \pm 109 \\ \text { Cerium } & 37.7481 & 6909 & 7248 \pm 245 \\ \text { Praseodymium } & 42.8215 & 6910 & 7342 \pm 79 \\ \text { Neodymium } & 42.6625 & 14686 & 15146 \pm 135 \\ \text { Samarium } & 89.2600 & 4338 & 4859 \pm 72 \\ \text { Europium } & 25.6482 & 4318 & 4377 \pm 123 \\ \text { Gadolinium } & 24.3251 & 2733 & 2791 \pm 55 \\ \text { Aluminum } & 15.6899 & 1070 & 1034 \pm 37 \\ \text { Calcium } & 29.7593 & 66 & (\mathrm{~b}) \\ \text { Iron } & 0.7751 & 4950 & 5117 \pm 240 \\ \text { Potassium } & 71.6125 & 216 & 198 \pm 5 \\ \text { Manganese } & 1.1187 & 237 & 239 \pm 8 \\ \text { Sodium } & 1.4596 & 671 & 715 \pm 35 \\ \text { Nickel } & 4.9628 & 228 & 232 \pm 9\end{array}$

(a) The analyzed concentrations are given at the $95 \%$ confidence limit.

(b) Analytical results were not available. 


\section{Appendix B - Preparation of Oxalic Acid Solutions}

The $0.9 \mathrm{M}$ oxalic acid solutions used for the precipitations were prepared by dissolving a measured mass of oxalic acid dihydrate $\left(\mathrm{H}_{2} \mathrm{C}_{2} \mathrm{O}_{4} \bullet 2 \mathrm{H}_{2} \mathrm{O}\right)$ in deionized water and diluting to a measured volume with deionized water. A summary of the solution preparation for each experiment is presented in Table B.1.

Table B.1 Preparation of Oxalic Acid Solutions

\begin{tabular}{|c|c|c|c|c|c|c|}
\hline Exp't & Manufacturer & Lot No. & $\begin{array}{c}\text { Assay } \\
(\%)\end{array}$ & $\begin{array}{c}\mathrm{H}_{2} \mathrm{C}_{2} \mathrm{O}_{4} \cdot 2 \mathrm{H}_{2} \mathrm{O} \\
\text { Mass } \\
\text { (grams) }\end{array}$ & $\begin{array}{c}\text { Solution } \\
\text { Volume } \\
\text { (liters) }\end{array}$ & $\begin{array}{l}\text { Conc'n } \\
\text { (moles/liter) }\end{array}$ \\
\hline $\begin{array}{l}\text { ACP-1 } \\
\text { ACP-2 } \\
\text { ACP-3 }\end{array}$ & E. M. Science & 32139330 & $99.5-102.5$ & 113.4594 & 1.000 & 0.900 \\
\hline $\begin{array}{l}\text { ACP-4 } \\
\text { ACP-5 }\end{array}$ & E. M. Science & 30268417 & $99.5-102.5$ & 113.4658 & 1.000 & 0.900 \\
\hline $\begin{array}{l}\text { ACP-6 } \\
\text { ACP-7 } \\
\text { ACP-8 } \\
\text { ACP-9 } \\
\text { ACP-10 } \\
\text { ACP-12 } \\
\text { ACP-13 }\end{array}$ & E. M. Science & 30268417 & $99.5-102.5$ & 226.9193 & 2.000 & 0.900 \\
\hline ACP-14 & $\begin{array}{l}\text { E. M. Science } \\
\text { E. M. Science }\end{array}$ & $\begin{array}{l}30268417 \\
30268417\end{array}$ & $\begin{array}{l}99.5-102.5 \\
99.5-102.5\end{array}$ & $\begin{array}{l}226.9171 \\
226.9610\end{array}$ & $\begin{array}{l}2.000 \\
2.000\end{array}$ & $\begin{array}{l}0.900 \\
0.900\end{array}$ \\
\hline
\end{tabular}

The oxalate precipitation completed during experiment ACP-11 was mistakenly performed using a $0.25 \mathrm{M}$ oxalic acid/ $0.5 \mathrm{M}$ nitric acid solution originally prepared as a precipitate wash solution (see Appendix C). Approximately 17.9 grams of $\mathrm{H}_{2} \mathrm{C}_{2} \mathrm{O}_{4} \bullet 2 \mathrm{H}_{2} \mathrm{O}$ were added to the graduated cylinder once the mistake was discovered to increase the excess oxalic acid concentration to $0.3 \mathrm{M}$. This addition assumed complete precipitation of the lanthanides and complete solubility of the metal impurities. 


\section{Appendix C - Preparation of Oxalic Acid/Nitric Acid Wash Solutions}

The $0.25 \mathrm{M}$ oxalic acid/0.5M nitric acid wash solutions were prepared by dissolving a measured mass of oxalic acid dihydrate $\left(\mathrm{H}_{2} \mathrm{C}_{2} \mathrm{O}_{4} \bullet 2 \mathrm{H}_{2} \mathrm{O}\right)$ in $0.5 \mathrm{M}$ nitric acid and diluting to a 2 liter volume with $0.5 \mathrm{M}$ nitric acid. The concentrated nitric acid used to prepare the $0.5 \mathrm{M}$ solutions was obtained from Fisher Scientific and assayed 69.6\% (15.7M). A summary of the solution preparation for each experiment is presented in Table C. 1 .

Table C.1 Preparation of Oxalic Acid/Nitric Acid Wash Solutions

$\begin{array}{llccccc}\text { Exp't } & \text { Manufacturer } & \text { Lot No. } & \text { Assay } & \begin{array}{c}\mathrm{H}_{2} \mathrm{C}_{2} \mathrm{O}_{4} \bullet 2 \mathrm{H}_{2} \mathrm{O} \\ \text { Mass } \\ \text { (grams) }\end{array} & \begin{array}{c}\text { Solution } \\ \text { Volume } \\ \text { (liters) }\end{array} & \begin{array}{c}\mathrm{H}_{2} \mathrm{C}_{2} \mathrm{O}_{4} \\ \text { Conc'n } \\ \text { (moles/liter) }\end{array} \\ \begin{array}{l}\text { ACP-6 } \\ \text { ACP-7 }\end{array} & \text { E. M. Science } & 30268417 & 99.5-102.5 & 63.0352 & 2.000 & 0.250 \\ \text { ACP-7 } & \text { E. M. Science } & 30268417 & 99.5-102.5 & 63.0395 & 2.000 & 0.250 \\ \text { ACP-8 } & \text { E. M. Science } & 30268436 & 99.5-102.5 & & & \\ \text { ACP-8 } & \text { E. M. Science } & 30268436 & 99.5-102.5 & 63.0353 & 2.000 & 0.250 \\ \text { ACP-10 } & & & & & & \end{array}$

The oxalate precipitate generated during experiment ACP-9 was not washed due to problems with the stirrer operation. 